\title{
Volume and temperature transports through the main Arctic Gateways: A comparative study between an ocean reanalysis and mooring-derived data
}

Marianne Pietschnig ${ }^{1,2}$, Michael Mayer ${ }^{1,2}$, Takamasa Tsubouchi ${ }^{3}$, Andrea Storto ${ }^{4}$, Sebastian 5 Stichelberger ${ }^{1}$, Leopold Haimberger ${ }^{1,2}$

${ }^{1}$ Department of Meteorology and Geophysics, University of Vienna, Vienna, Austria

${ }^{2}$ Austrian Polar Research Institute, Vienna, Austria

${ }^{3}$ Physical Oceanography of the Polar Seas group, Alfred Wegener Institute for Polar and Marine Research, Bremerhaven, Germany

$10{ }^{4}$ Ocean Modeling and Data Assimilation Division, Centro Euro-Mediterraneo sui Cambiamenti Climatici, Bologna, Italy Correspondence to: Marianne Pietschnig (mp586@exeter.ac.uk), Current affiliation: Department of Mathematics, University of Exeter, Exeter, UK

\begin{abstract}
Oceanic transports through the Arctic gateways represent an integral part of the polar climate system, but comprehensive in-

15 situ-based estimates of this quantity have been lacking in the past. New observation-based estimates of oceanic volume, temperature and freshwater transports have recently become available. Those estimates have been derived from moored observations in the four major gateways by applying mass and salinity constraints. We seize this opportunity to compare a recent ocean reanalysis release with those observation-based estimates. First, time series of integrated volume and temperature transports through each strait are considered. Good agreement is found for Davis Strait volume transports, but considerable

20 disagreement of up to 1.1 Sv in Fram Strait and the Barents Sea Opening. The annual mean net volume export through the gateways is $-0.03 \pm 0.23 \mathrm{~Sv}$ in the reanalysis, weaker than the $-0.15 \pm 0.06 \mathrm{~Sv}$ derived from the observation-based estimate (uncertainties represent the monthly standard deviation). The net ocean heat transport to the Arctic Ocean is similar in the two datasets (observation-based: $153 \pm 44 \mathrm{TW}$, reanalysis: $145 \pm 35 \mathrm{TW}$ ). Discrepancies in the integrated transports are further investigated by studying cross-sections of velocity, temperature and temperature flux density. These reveal good qualitative agreement in all straits, but considerable differences in the strength of major features like the East Greenland Current and the West Spitzbergen Current. Examination of the instrumental coverage reveals that areas of discrepancy are often co-located with poorly observed regions. In conclusion, both types of data sets have their merits and are recommended to be used complementarily for climate studies in this data-sparse region. We hope that the results presented in this study can assist in planning future observational efforts and in the development of ocean reanalysis products.
\end{abstract}


Ocean Sci. Discuss., https://doi.org/10.5194/os-2017-98

Manuscript under review for journal Ocean Sci.

Discussion started: 15 December 2017

(c) Author(s) 2017. CC BY 4.0 License.

\section{Introduction}

Research in the Arctic region is motivated by observed changes in the Arctic climate, including a downward trend in sea ice extent and thickness over the past few decades (Comiso et al., 2008; Kwok and Rothrock, 2009; Parkinson and Comiso, 2013; Stroeve et al., 2012) and above-global-average surface air temperature increase (Serreze et al., 2009). These changes affect

5 the mean and the seasonal cycle of the coupled Arctic energy budget, including atmosphere, ocean, and sea ice (Mayer et al., 2016).

Ocean heat transport is a relevant part of the Arctic energy budget, contributing approximately $10 \%$ to the total energy transport into the polar cap. The oceanic transport is roughly $150 \mathrm{TW}$ (Tab. 1), compared to $1290 \mathrm{TW}$ transported by the

10 atmosphere (derived from $84 \mathrm{~W} / \mathrm{m}^{2}$ multiplied by the ocean surface area of the Arctic domain $15.4 \times 10^{6} \mathrm{~km}^{2}$, Serreze et al., 2007). Ocean heat transport also exhibits considerable variability on inter-annual timescales modulating the Arctic energy budget (Årthun et al., 2012; Mayer et al., 2016). However, there is no consensus among climate models on the contribution of oceanic transports to Arctic warming (Burgard and Notz, 2017). Reliable observation-based estimates of this important physical quantity are therefore needed to better understand involved processes. Ocean heat transport is difficult to observe directly and thus ocean and sea-ice retrospective analyses (or "reanalyses") represent a valuable data source for this purpose.

Reanalyses provide the four-dimensional state of the ocean and sea-ice constrained by available observations over multidecadal time periods, albeit with large uncertainties in data-sparse regions like the Arctic. The development and continuous improvement of reanalysis products facilitates the investigation of mechanisms involved in the aforementioned changes,

20 especially in remote regions with limited observational coverage (Balmaseda et al., 2013). A reanalysis consistently uses the same modeling and data assimilation framework throughout the analysed period and ingests quality controlled observational datasets. The ocean reanalysis chosen for our study is the Centro Euro-Mediterraneo sui Cambiamenti Climatici (CMCC) Global Ocean Reanalysis C-GLORS version 7. Assessing the reliability of reanalyses is crucial for qualifying these datasets for long-term studies. An important method for validating ocean reanalysis products is to compare the output fields or derived quantities with observation-based estimates (Masina et al., 2011). Ideally, those observations are "independent", meaning that they are not assimilated in the reanalysis. In-situ measurements of currents, which are usually not assimilated, are therefore well-suited for validation purposes (Masina et al., 2011).

Over many years, the four major Arctic gateways which connect the Arctic Ocean to the Atlantic and Pacific Ocean have been 30 monitored by several research groups in the world (Dickson et al., 2008). Tsubouchi et al. (2017b) quantify, for the first time, the seasonal cycle of ocean and sea ice net heat and fresh water fluxes around the Arctic ocean boundary based on observational data from the moored array using a box inverse model. These moorings are not included in the UK Met Office Hadley Centre EN4 dataset (Good et al., 2013), which contains the temperature and salinity profiles assimilated in C-GLORS (Storto, 2016; 
Ocean Sci. Discuss., https://doi.org/10.5194/os-2017-98

Manuscript under review for journal Ocean Sci.

Discussion started: 15 December 2017

(c) Author(s) 2017. CC BY 4.0 License.

Discussions

(c) (i)

Storto and Masina, 2016b). Therefore, this observation-based dataset (OBS) presents a largely independent dataset for comparison with the C-GLORS reanalysis, except in the Barents Sea Opening (see Sect. 2.2 for further discussion). Tsubouchi et al. (2017b) focus on the period from September 2005 to August 2006. We examine C-GLORS and OBS transports and state quantities for this one-year period. The region for comparing C-GLORS with OBS is defined by the locations of moorings in

5 the Arctic Gateways. In the present study, the Arctic Ocean is therefore defined to be north of Davis Strait, similar to Haine et al. (2015), and not north of the Canadian Arctic Archipelago (CAA) as in Serreze et al., (2007). Figure 1 shows a map of those gateways, as well as the volume transports for the main currents through those straits as estimated in this study.

Adopting a slightly altered notation from Bacon et al. (2015), we denote transports or fluxes with F, and use the subscripts ' $\mathrm{V}$ '

10 for volume, ' $\theta$ ' for temperature and ' $m$ ' for mass. Schauer and Beszczynska-Möller (2009) explained that whenever the net volume transport $\left(\mathrm{F}_{\mathrm{V}}\right)$ into a study area is not equal to zero, the choice of reference temperature will affect the temperature transport through this section. Consequently, we adopt the term 'temperature transport $\left(\mathrm{F}_{\theta}\right)$ ' for single straits, reserving the term 'heat transport' for study areas in which the volume transport is balanced. Even though it is not possible to calculate 'heat' transports through individual straits, it is certainly of interest to compare the temperature transports from both datasets

15 (provided that the same reference temperature is used for calculating them) and to see the contributions of individual straits to the total heat transport into the Arctic Ocean.

Two different methods to compare C-GLORS with OBS are employed: First, we investigate time series of monthly volume and temperature transports integrated across the individual straits. Second, cross-sections of velocity, potential temperature and temperature flux density are plotted for both datasets. Discrepancies in the spatial distribution of those three quantities across the straits can then be linked to the comparison of the integrated transports. Previous studies comparing cross-sections obtained from models or reanalyses against observational data in the Arctic Gateways include Kawasaki and Hasumi (2016), Zuo et al. (2011) and Fieg et al. (2010).

25 In Zuo et al. (2011) and other previous studies examining integrated transports through all of the Arctic Gateways, the observation-based estimates are compiled from various authors who calculate transports for individual straits. Those estimates are therefore not necessarily consistent with each other and might not be suitable for Arctic mass and energy budget evaluations. For example, volume fluxes are sensitive to the period under consideration due to the large inter-annual variability in some of the straits. Additionally, quality control of hydrographic observations and methods to derive volume transports

30 from those observations can differ among authors. Using one source of data is also preferable for calculating temperature transports, as one can consistently define the reference temperature for all straits. The observation-based dataset used here is unique because of its homogeneity in the processing of the observational datasets to provide consistent transport estimates across the major Arctic gateways. We believe that it is valuable to extend previous efforts and investigate cross-sections and 
Ocean Sci. Discuss., https://doi.org/10.5194/os-2017-98

Manuscript under review for journal Ocean Sci.

Discussion started: 15 December 2017

(c) Author(s) 2017. CC BY 4.0 License.

integrated transports in one comprehensive study. We now have the opportunity to do so since an internally consistent mooringderived dataset has become available through PANGAEA (Tsubouchi et al., 2017a).

The paper is structured as follows: We provide a brief overview of the observation-based data and the reanalysis in Sect. 2.

5 The methods are introduced in Sect. 3. Results of our comparison of time series and cross-sections are presented in Sect. 4. In the last section, we summarize the results, draw conclusions, and give an outlook for further research.

\section{Data}

\subsection{Observation-based data (OBS)}

The four major Arctic gateways (Davis, Fram and Bering Strait and the Barents Sea Opening) have been monitored by several

10 research groups for many years (Dickson et al., 2007; Haine et al., 2015). Integrating the individual mooring arrays across the Arctic boundary, Tsubouchi et al. (2017b) quantify the seasonality of oceanic volume, heat and freshwater transports under mass and salinity constraints. The study focuses on the period from September 2005 to August 2006, which is the first year for which comprehensive mooring observations of the Arctic boundary are available. The complete observation of all major gateways commenced in October 2004, but several instruments in the western part of deep Fram Strait (designed to capture the variability of the East Greenland Current) could not be fully recovered in that year.

The main data source are 138 moored instruments spread across the Arctic gateways. The instruments include temperatureand salinity-measuring devices (SeaBird Electronics MicroCATs, SBE), acoustic Doppler current profilers (ADCP) taking velocity profiles, and single-point current meters (Aanderaa RCMs) which measure temperature, velocity and in some cases

20 also salinity. In the Barents Sea Opening (BSO), where instrumental coverage is limited, the moorings are supplemented by hydrographic measurements from nine cruises conducted during the period September 2005 to August 2006. The locations and types of moored instruments in the individual straits are shown in Fig. 3 - 7. Detailed descriptions of the moorings in each strait can be found in Curry et al. (2014) for Davis Strait, Beszczynska-Möller et al. (2012) for Fram Strait, Ingvaldsen et al. (2004) for the BSO and in Woodgate et al. (2015) for Bering Strait. Model output from the Nucleus for European Modelling

25 of the Ocean (NEMO) with $1 / 12^{\circ}$ resolution is used in regions where moored observations are lacking. This includes the upper ocean above the shallowest instruments (located at 50-100 m depth depending on the gateway) and in the shelf regions: Belgica Bank in Fram Strait and north of Bear Island in the BSO. Sea ice transport is estimated using Pan-Arctic Ice Ocean Modeling and Assimilation System output (PIOMAS, Zhang and Rothrock, 2003).

30 The observational data are vertically and horizontally interpolated to fill a regular grid with $3 \mathrm{~km}$ horizontal spacing (given by the resolution of NEMO $1 / 12^{\circ}$ data) and 1 dbar vertical spacing. The actual interpolation scheme differs slightly from gateway 
Ocean Sci. Discuss., https://doi.org/10.5194/os-2017-98

Manuscript under review for journal Ocean Sci.

Discussion started: 15 December 2017

(c) Author(s) 2017. CC BY 4.0 License.

Discussions

(c) $($ P)

to gateway, depending on the instrument types and data coverage. In Davis Strait for example, velocities are extrapolated from the deepest measurements at $500 \mathrm{~m}$ to zero velocity at the ocean bottom. In the BSO, velocity measurements are sparse, so geostrophic velocities are derived from salinity and temperature data. Then, mass and salinity conserved monthly fields of velocity are derived using a box-inverse model for the consecutive twelve months (see Tsubouchi et al. (2017b) for the full

5 description of data treatment in the individual straits). The main outcomes of the study such as twelve monthly oceanic transport time series and temperature, salinity and velocity fields, are available through the data publisher PANGAEA (Tsubouchi et al., 2017a). It is worth mentioning that the effective spatial resolution of the output fields is limited by the moored instrument positions. They are typically located 100-1000 m apart in the vertical and 20-50 km apart in horizontal direction.

\section{2.2. C-GLORSv7}

The CMCC Global Ocean Physical Reanalysis System (C-GLORSv7) is an ocean reanalysis at eddy-permitting resolution (approximately $1 / 4^{\circ}$ ) with 75 vertical depth levels. C-GLORSv7 covers the period from 1993 to 2016 and is being updated in delayed time mode, with a lag of approximately one year. The ocean model component of C-GLORSv7 is NEMO (Madec, 2008) version 3.6, which is implemented on the tripolar ORCA025 grid with Arakawa C-grid staggering and partial steps

15 (Bernard et al., 2006). The resolution of the model allows eddies to be resolved approximately between $50^{\circ} \mathrm{S}$ and $50^{\circ} \mathrm{N}$ (Penduff et al., 2010). The resolution is higher in the Arctic region (about $9 \mathrm{~km}$ ) compared to low latitudes, but at the same time the Rossby radius is smaller here (about $10 \mathrm{~km}$ in the deep basins) so that the reanalysis is not eddy-resolving in our study region (Bacon et al., 2015). The sea-ice model LIM2 is coupled to NEMO at a 2-hourly frequency. LIM2 is a three-layer (two of sea ice and one of snow) thermodynamic-dynamic sea-ice model that implements elasto-visco-plastic rheology (Bouillon et

20 al., 2009). The model is forced by the European Centre for Medium Range Weather Forecasts (ECMWF) ERA-Interim reanalysis (Dee et al., 2011) using the CORE bulk formulas (Large and Yeager, 2009).

C-GLORSv7 assimilates all hydrographic profiles from XBTs (expendable bathythermographs), CTDs (ConductivityTemperature-Depth), Argo floats, moorings and sea-mammals extracted from the UK Met Office EN4 dataset (Good et al.,

25 2013) and along-track altimetry data provided by AVISO (Archiving, Validation and Interpretation of Satellite Oceanographic data, Le Traon and Ogor, 1998) through a three-dimensional variational (3DVAR) data assimilation system with first guess at appropriate time (FGAT). The 3DVAR/FGAT assimilation scheme corrects the model fields every seven days. Backgrounderror covariances are derived from monthly anomalies with respect to long-term averages from a free simulation (Storto et al., 2014) and have been re-tuned to match output assimilation statistics as the ones proposed by Desroziers et al. (2005).

30 Additionally, C-GLORSv7 implements a surface nudging scheme to assimilate sea surface temperature daily analyses from Reynolds et al. (2007), sea-ice concentration data from the Met.no OSI-SAF reprocessed dataset and, in the Arctic Ocean, seaice thickness reconstructions from PIOMAS. A large-scale bias correction scheme is also implemented to reduce model biases 
Ocean Sci. Discuss., https://doi.org/10.5194/os-2017-98

Manuscript under review for journal Ocean Sci.

Discussion started: 15 December 2017

(c) Author(s) 2017. CC BY 4.0 License.

and drifts (Storto et al., 2016). The data assimilation of C-GLORSv7 includes an improved scheme for the quality control of observations (Storto, 2016).

None of the moorings which are used in preparation of OBS were assimilated in the reanalysis, but CTD data from several cruises were assimilated in the Barents Sea Opening during seven months throughout the study period. In this case, OBS is only independent of the reanalysis concerning velocities, but not temperature or salinity, since the sparse moored observations are supplemented by vessel based CTD data in this strait. In Fram Strait and Davis Strait, CTD data are assimilated for one month each, namely November 2005 for Fram Strait and July 2006 for Davis Strait. No temperature or salinity data are assimilated in Bering Strait, so that OBS is largely independent of the reanalysis in those three straits.

The latest release of C-GLORS (v7) is now part of the Copernicus Marine Environment Monitoring Service (CMEMS, http://marine.copernicus.eu) and is freely released through the website http://c-glors.cmcc.it. We conduct our comparisons between OBS and the reanalysis for C-GLORSv7 without (v7 control) and with (v7) data-assimilation and surface nudging to investigate the influence of the sparse observations on the reanalysis at such high latitudes. We are interested in the performance of C-GLORSv7 in the Arctic Ocean, as this reanalysis is one of the state-of-the-art ocean reanalysis products that are currently available. Previous releases of C-GLORS have been validated extensively on a global scale (Storto et al., 2016; Storto and Masina, 2016a). C-GLORS has also been used for a variety of climate applications, including studies investigating North Atlantic Ocean climate variability (Yang et al., 2016) and the energy budget of the Arctic cap (Mayer et al., 2016). Additionally, biogeochemical, fishery and larval disposal models are coupled off-line to C-GLORS. Other ocean reanalyses

20 with the same resolution as C-GLORS include UR025.4 (Valdivieso and Haines, 2013), GLORYS2v4 (Garric and Parent, 2017) and GLOSEA5 (MacLachlan et al., 2015), all with 75 vertical levels. It is unfair to consider any of those reanalysis products superior to the others, but we briefly mention that UR025.4 assimilates EN3 (Ingleby and Huddleston, 2007) data, which incorporates fewer observations than EN4, especially in the Arctic (Good et al., 2013). GLORYS2v4 uses a slightly older ocean model version (NEMO version 3.0) than C-GLORSv7 (NEMO v3.6).

\section{3. Materials and Methods}

Following Bacon et al. (2015), the vertically integrated mass balance of the liquid Arctic Ocean with volume V and lateral boundary A (represented by the oceanic straits) can be expressed through

$$
\iiint_{V} \frac{\partial \rho_{w}}{\partial t} d V=\iint_{A} \rho_{w} v_{\perp} d s d z+F_{m}{ }^{s} .
$$

Here, $\rho_{\mathrm{w}}$ is the density of sea water (set to $1026 \mathrm{~kg} / \mathrm{m}^{3}$ ), $\mathrm{v}_{\perp}$ is the velocity component normal to the lateral boundary A (positive northward and eastward in the Barents Sea Opening). Integration is with respect to ds and dz, which represent horizontal and 
Ocean Sci. Discuss., https://doi.org/10.5194/os-2017-98

Manuscript under review for journal Ocean Sci.

Discussion started: 15 December 2017

(c) Author(s) 2017. CC BY 4.0 License.

Discussions

(c) (i)

vertical coordinates along A, respectively. This equation expresses the fact that under stationary conditions (when the lefthand side equals zero), horizontal export of mass balances the surface freshwater flux ( $\mathrm{F}_{\mathrm{m}}^{\mathrm{S}}$, the superscript " $\mathrm{S}$ " stands for surface). $\mathrm{F}_{\mathrm{m}} \mathrm{S}$ is the difference between the sum of precipitation $\mathrm{P}$, river runoff $\mathrm{R}$ and ice melt $\mathrm{M}$ (all are positive downward) and evaporation $\mathrm{E}$ (positive upward). $\mathrm{F}_{\mathrm{m}} \mathrm{s}$ is defined positive downward.

First, monthly fields of meridional and zonal volume transports and temperature transports are calculated from reanalysis fields for each point and vertical level on the model-native (tripolar) grid. The transports for each grid cell are denoted with an asterisk $\left(\mathrm{F}_{\mathrm{V}} *\right.$ and $\left.\mathrm{F}_{\theta}^{*}\right)$, so they are distinguishable from the integrated transports through the straits. Computation of $\mathrm{F}_{\mathrm{V}} *$ is straightforward, using velocity fields and vertical and horizontal geometry of the staggered reanalysis grid. $\mathrm{F}_{\theta} *$ is calculated

10 using

$F_{\theta}^{*}=\rho_{w} c_{p}\left(\bar{\theta}-\theta_{\text {ref }}\right) \cdot \overline{v_{2}} \cdot A_{c}$

where $c_{p}=3990 \mathrm{~J} / \mathrm{kgK}$. We use $\theta_{\text {ref }}=0{ }^{\circ} \mathrm{C}$, which minimizes the influence of the small net volume export from the Arctic

15 region onto the net temperature transport (see Sect. 4.1). Potential temperature is denoted by $\theta$ and the component of the horizontal velocity (zonal on the $\mathrm{u}$-grid and meridional on the v-grid) by $\mathrm{v}_{2}$. The overbar indicates monthly averages, and $\mathrm{A}_{\mathrm{c}}$ stands for the vertical area of the respective grid cell. The temporal resolution of C-GLORS output is daily, but due to the monthly resolution in the observation-based dataset, $\mathrm{F}_{\theta} *$ is computed as described above. Calculating the temperature transport with the same reference temperature for both the reanalysis and OBS is essential and makes it possible for us to compare the transports through each strait between the two datasets. A comparison of temperature transports through individual straits to other studies which use a different reference temperature is not possible.

Second, the C-GLORS grid points ('transport points'), which are closest to the grid of the mooring-derived data, are identified in each strait (see Fig. S1 - S4 in the supporting information). Vertically integrated $\mathrm{F}_{\mathrm{V}} *$ and $\mathrm{F}_{\theta} *$ in each of those points are summed up over the respective strait, using meridional transports and zonal transports according to the location of the points on the staggered grid. The vertically integrated transport in each point corresponds to the transport through the water column with the width of one grid cell centered on the respective point. The limits of integration are the ocean bottom and the sea surface. Thus, we are neglecting the contribution of transports through the steric sea surface height (Storto et al., 2015). We obtain a closed line integral, giving the monthly transport through each strait by summing up the values at all 'transport points'. Finally, the time series of temperature and volume transports can be plotted for our one-year study period.

Third - in preparation for the cross-section plots - the C-GLORS velocity vector in each transport point is computed by interpolating meridional velocities (given on the v-grid) onto the u-grid, and zonal velocities (given on the u-grid) onto the vgrid. Meridional and zonal directions are derived from the grid geometry. The velocity vector is then projected onto the unit 
Ocean Sci. Discuss., https://doi.org/10.5194/os-2017-98

Manuscript under review for journal Ocean Sci.

Discussion started: 15 December 2017

(c) Author(s) 2017. CC BY 4.0 License.

vector normal to the observation-based grid, thus obtaining the C-GLORS velocity in the direction of the observation-based flow. For the temperature flux densities, $\bar{\theta}$ is interpolated to the transport points and multiplied by the monthly average of the projected velocity. For the mooring-derived temperature transports, potential temperatures are linearly interpolated from the temperature and salinity grid (with 643 data points) to the velocity grid (with 639 data points), and multiplied with the velocities and appropriate constants (Eq. 2). The observation-based temperature, temperature flux density and velocity fields are then horizontally averaged over the appropriate grid points to match the horizontal resolution of the reanalysis for the cross-section plots. Similarly, C-GLORS fields are vertically interpolated to meet the higher resolution of the observation-based grid. Finally, cross-sections showing the distribution of potential temperature, velocity and temperature flux density (in $\mathrm{W} / \mathrm{m}^{2}$ ) across each strait are prepared.

We note that the error introduced by using monthly mean $\theta$ and velocity fields for calculating monthly temperature transports (see Eq. 2) instead of using the daily fields is small. Following for example Peixoto and Oort (1992), the product of Reynolds decomposed temperature and velocity fields gives $\overline{v_{2} \cdot \theta}=\overline{v_{2}} \cdot \bar{\theta}+\overline{v_{2}{ }^{\prime} \cdot \theta^{\prime}}$. The overbar denotes monthly means, while the primed quantities represent daily fields. This expression states that the monthly mean temperature transport $\overline{v_{2} \cdot \theta}$ (obtained

15 by multiplying daily fields and then averaging over each month) can be split up into the 'stationary circulation' (first term on the righthand side) and the contribution from 'transient eddies', i.e. sub-monthly scale fluctuations. Based on the C-GLORS data, we find that the correlation of daily $\theta$ and $v$ fields contributes less than $13 \%$ to the total monthly temperature transport through each strait, with largest relative effects in Davis Strait and largest absolute influence in the BSO (see Fig. S5 in the supporting information). Horizontal temperature transports at those high latitudes therefore seem to be dominated by the stationary circulation (Valdivieso et al., 2014).

The argument above for neglecting sub-monthly temporal eddies has no implication for the importance of spatial eddies for the circulation in the Arctic gateways or for vertical temperature transport (Hattermann et al., 2016). Several authors discuss the need for reanalyses and observations with high spatial resolution, in order to capture the entire transport through the Arctic gateways due to the small Rossby radius of deformation at high latitudes (Beszczynska-Möller et al., 2011; Drange et al., 2005; Hattermann et al., 2016). Hattermann et al (2016) use a high resolution regional model with $800 \mathrm{~m}$ grid spacing to study the contribution of mesoscale eddies to the recirculation of Arctic Water in Fram Strait. As previously discussed by de Steur et al. (2014), the strength of the observed East Greenland Current is highly sensitive to the latitudinal position of the moorings. A relocation of the moored array in 2002 from $79^{\circ} \mathrm{N}$ to $78.5^{\circ} \mathrm{N}$ lead to an increase in the observed volume transport of almost 3

30 Sv compared to the years preceding the southward shift. 
Ocean Sci. Discuss., https://doi.org/10.5194/os-2017-98

Manuscript under review for journal Ocean Sci.

Discussion started: 15 December 2017

(c) Author(s) 2017. CC BY 4.0 License.

\section{Results}

The comparison between C-GLORSv7 and the observation-based time series (Fig. 2, Tab. 1) reveals that there is considerable disagreement in the transports through the individual straits. The average volume transport is closest to the observation-based estimate in Davis Strait (- $2.1 \pm 0.7 \mathrm{~Sv}$ from the observation-based data, $-2.3 \pm 0.4 \mathrm{~Sv}$ from C-GLORSv7). On a month-to5 month basis the timeseries from the reanalysis closely follow the observation-based timeseries in Bering Strait and the BSO, which is also reflected in high correlation coefficients between the two datasets for Bering Strait (0.97) and the BSO (0.76). All transport estimates are presented with the monthly standard deviation $(1 \sigma)$, which mainly represents the temporal variability during the one-year study period, rather than being a measure for the uncertainty of the results.

\subsection{Net transport}

10 The net (sum over all straits) volume transport out of the Arctic region is $-0.03 \pm 0.23 \mathrm{~Sv}$ from C-GLORSv7 and $-0.15 \pm 0.06$ Sv based on OBS (Tab. 1 and Fig. 2). Even though the absolute difference is small, the relative discrepancy is quite substantial and the temporal variability of C-GLORSv7 is a factor of four larger than in OBS. The volume export is due to a positive timemean $\mathrm{F}_{\mathrm{m}} \mathrm{s}$. For computation of the observation-based data, the initial surface freshwater flux is set to $0.18 \mathrm{~Sv}$, based on climatological 'P minus E' and R values compiled from a few different sources (Tsubouchi et al., 2012). We would like to

15 point out that the observation-based volume transport estimate of $-0.15 \pm 0.06 \mathrm{~Sv}$ together with the volume transport by sea ice (- $0.07 \mathrm{~Sv}$, derived from $-2080 \mathrm{~km}^{3} / \mathrm{yr}$ (Haine et al., 2015) using $1 \mathrm{~Sv}=31,536 \mathrm{~km} / \mathrm{yr}$ ) nicely balances the $0.20 \pm 0.08 \mathrm{~Sv}$ surface freshwater flux obtained from the inverse-model calculations, as discussed by Tsubouchi et al. (2017b). This is also in excellent agreement with the updated surface freshwater flux estimate $(0.203 \pm 0.016 \mathrm{~Sv}$ or $6400 \mathrm{~km} 3 / \mathrm{yr}$, Carmack et al., 2016). In C-GLORS, 'P minus E' is derived from ERA-Interim, and a climatological $\mathrm{R}$ is used as well as a damping term to satisfy

20 global conservation requirements (Storto and Masina, 2016b).

The net heat transport integrated over the study area is slightly larger in OBS (153 $\pm 44 \mathrm{TW})$ than in C-GLORSv7 (145 \pm 35 TW, Tab. 1) and match within the temporal variability. Technically, these integrated transports are still dependent on the reference temperature because of the (small) net volume flux discussed above. However, based on the product of the average temperature of the Arctic Ocean boundary $\left(1.1 \pm 0.2{ }^{\circ} \mathrm{C}\right.$ from both datasets) with the respective net volume transports and appropriate constants, we find that the contribution of the net mass flux to the net temperature transport is negligible (- $0.60 \pm$ $0.24 \mathrm{TW}$ for the observation-based data, $-0.07 \pm 1.06 \mathrm{TW}$ for C-GLORSv7) due to the appropriate choice of $\theta_{\text {ref. }}$ Hence, the term heat transport seems appropriate in this case. Moreover, $\mathrm{F}_{\theta}$ differences between C-GLORSv7 and the observation-based estimates cannot be attributed to the difference in their respective net $F_{V}$ values. 
Ocean Sci. Discuss., https://doi.org/10.5194/os-2017-98

Manuscript under review for journal Ocean Sci.

Discussion started: 15 December 2017

(c) Author(s) 2017. CC BY 4.0 License.

Discussions

(c) (i)

\subsection{Davis Strait}

The volume export through Davis Strait derived from the reanalysis (- $2.3 \pm 0.4 \mathrm{~Sv}$ ) is close to the observation-based estimate (- $2.1 \pm 0.7 \mathrm{~Sv}$, Tab. 1). However, the discrepancy between $\mathrm{F}_{\theta}$ obtained from C-GLORSv7 (5 $\left.\pm 4 \mathrm{TW}\right)$ and OBS $(29 \pm 10 \mathrm{TW})$ is substantial. $\mathrm{F}_{\theta}$ is much closer to the observation-based estimate in the control experiment (C-GLORSv7 control: $23 \pm 10$

5 TW, Tab. 1). Based on the University of Reading reanalysis product UR025.1 with $1 / 4^{\circ}$ resolution and 46 vertical levels, Zuo et al. (2011) estimated a multi-annual averaged FV through Davis, Fury and Hecla Straits of - $2.4 \pm 0.4$ Sv for the period 1987 to 2004. The estimates derived from both C-GLORSv7 and OBS seem realistic compared to this literature value. Curry et al. (2014) give an estimate of the annual $\mathrm{F}_{\mathrm{V}}$ through Davis Strait of - $1.6 \pm 0.5 \mathrm{~Sv}$, based on data from the moored array for the period 2004 - 2010. This value is lower than the estimates presented here, partly because this average includes the year 2007,

10 during which exports through Davis Strait were anomalously low (- 1.3 $\pm 0.4 \mathrm{~Sv}$, Curry et al., 2014). As far as $\mathrm{F}_{\theta}$ is concerned, Curry et al. (2011) presented an estimate of $20 \pm 9 \mathrm{TW}$ (referenced to $0{ }^{\circ} \mathrm{C}$ ) based on data from the moored array between 10/2004 and 09/2005, which is clearly closer to OBS than to the C-GLORSv7 estimate obtained in the present study.

The cross-section plots for Davis Strait from OBS (Fig. 3a, left column) show that there is a northward current in eastern Davis

15 Strait (east of $57^{\circ} \mathrm{W}$, distance $\mathrm{d}=200 \mathrm{~km}$ in the plots), transporting $1.2 \pm 0.7 \mathrm{~Sv}$ (Fig. 1) of relatively warm water (area and time averaged temperatures of $2.4 \pm 0.5^{\circ} \mathrm{C}$ ) into the Arctic Ocean. The temperature transport is therefore $22 \pm 12 \mathrm{TW}$ in this region in OBS. In C-GLORSv7 (Fig. 3a, middle column), there is a small northward current in this area but mostly the velocities are close to zero. The average transport is $-0.1 \pm 0.7 \mathrm{~Sv}$ (C-GLORSv7, Fig. 1), with negative transports between January and July. This is in contrast to OBS, where the currents remain northward throughout the study period. The average 20 temperature of the current is $2.0 \pm 0.2{ }^{\circ} \mathrm{C}$ in C-GLORSv7, resulting in a temperature transport of $1 \pm 7 \mathrm{TW}$. According to Beszczynska-Möller et al. (2011), the flow in this region is observed to be northward. It consists of Arctic waters in the West Greenland Current above the shelf and the West Greenland Slope Current of Atlantic origin. In the remainder of Davis Strait ( $d=0$ to $200 \mathrm{~km}$ ), which includes the strong southward Baffin Island Current, the volume export in OBS is greater $(-3.4 \pm 0.7$ Sv, Fig. 1) than in C-GLORSv7 (- $2.2 \pm 0.6 \mathrm{~Sv})$. Temperatures are generally lower than in the East $\left(0.6 \pm 0.3{ }^{\circ} \mathrm{C}\right.$ OBS, $1.1 \pm$ $0.1{ }^{\circ} \mathrm{C}$ C-GLORSv7). This results in temperature transports of $9 \pm 4$ TW (OBS) and $0 \pm 5$ TW (C-GLORSv7).

The agreement is better in both parts of Davis Strait for the control experiment (Fig. 3b). In eastern Davis Strait, we find an average northward flow of $0.3 \pm 0.4 \mathrm{~Sv}$ and $2.4 \pm 0.8{ }^{\circ} \mathrm{C}$ warm waters in the control experiment. The predominantly northward current (except for January - March), combined with the year-round positive temperatures results in an average temperature

30 transport of $11 \pm 9 \mathrm{TW}$, which is closer to OBS compared to the full C-GLORSv7 experiment. The agreement is also better between the control experiment $\left(\mathrm{F}_{\mathrm{V}}=-3.1 \pm 0.5 \mathrm{~Sv}, \theta=0.5 \pm 0.2{ }^{\circ} \mathrm{C}, \mathrm{F}_{\theta}=7 \pm 2 \mathrm{TW}\right)$ and $\mathrm{OBS}$ in western Davis Strait. It seems like the stronger inflow and outflow in the control experiment compared to the full C-GLORSv7 can be related to the 
Ocean Sci. Discuss., https://doi.org/10.5194/os-2017-98

Manuscript under review for journal Ocean Sci.

Discussion started: 15 December 2017

(c) Author(s) 2017. CC BY 4.0 License.

stronger horizontal temperature gradient in the control experiment in the upper $300 \mathrm{~m}$. This implies a stronger zonal density gradient, which, assuming geostrophic balance, could explain the enhanced patterns of meridional velocities in Davis Strait.

Instrumental coverage in Davis Strait above $500 \mathrm{~m}$ is relatively high (see Fig. 3a). However, some of the instruments did not record any data during the study period or parts of it (see supporting information of Tsubouchi et al., 2017b). This is true close to Baffin Island in the West and over the slope in Eastern Davis Strait, which are regions of major discrepancy between OBS and C-GLORSv7.

To facilitate the comparability to other studies which define the boundary of the Arctic Ocean to be north of the CAA, we 10 investigate the volume and temperature transport through Baffin Bay in C-GLORSv7 during the study period. The sum of the transports through Lancaster Sound (LS), Cardigan Strait (CS), Hell Gate (HG) and Nares Strait is $8 \pm 2$ TW and $-1.9 \pm 0.4$ Sv. The contributions from the individual straits are $-0.6 \pm 0.2 \mathrm{~Sv}$ and $2.7 \pm 0.7 \mathrm{TW}$ (LS), $0.25 \pm 0.08 \mathrm{~Sv}$ and $1.2 \pm 0.5 \mathrm{TW}$ (CS), zero contribution from HG and the largest contribution from Nares Strait ( $1.1 \pm 0.2 \mathrm{~Sv}$ and $3.9 \pm 0.6 \mathrm{TW})$. The volume transport estimates are in good agreement with observation-based estimates in all straits (Lancaster Sound: - 0.53 Sv, 1998 -

15 2006, Peterson et al., 2012, Cardigan Strait plus Hell Gate: - 0.3 Sv, 2000 - 2002, Melling et al., 2008, Nares Strait: 1.03 Sv, 2007 - 2009, Münchow, 2016). The high temperature transport through the Canadian Straits is due to both volume transports and average temperatures being negative $\left(-0.29 \pm 0.06{ }^{\circ} \mathrm{C}\right.$ average over all straits from C-GLORSv7) throughout the year in the Canadian Straits.

20 After passing through Baffin Bay, the temperature transport through Davis Strait is only $5 \pm 4$ TW and the volume export is $2.3 \pm 0.4 \mathrm{~Sv}$. The roughly 0.4 Sv stronger outflow from Baffin Bay through Davis Strait compared to the inflow through the Canadian Straits is consistent with Curry et al. (2011), who report a difference between the two of 0.6 Sv (with a total of - 1.7 Sv through the Canadian Straits and - 2.3 Sv through Davis Strait). In addition to CAA outflow, the net transport through Davis Strait includes river runoff, contributions from the Greenland Ice Sheet and sea ice melt in Baffin Bay, as well as precipitation minus evaporation, so it is not surprising that the volume export is larger in Davis Strait compared to the CAA (BeszczynskaMöller et al., 2011; Curry et al., 2011). The lower temperature transports through Davis Strait (5 TW) compared to the Canadian Straits (8 TW) would imply an energy divergence out of Baffin Bay, which is unlikely as heat loss to the atmosphere is expected in the bay (Rudels, 2011). It appears likely that the energy divergence is a result of too weak temperature imports through eastern Davis Strait in the reanalysis. Using the temperature transport through Davis Strait obtained from OBS (29 TW) gives an energy convergence of $21 \mathrm{TW}$, which is equivalent to a heat loss of approximately $30 \mathrm{~W} / \mathrm{m}^{2}$ through the surface in Baffin Bay $\left(\right.$ area $=689000 \mathrm{~km}^{2}$ ). This estimate is in good agreement with the $28-38 \mathrm{~W} / \mathrm{m}^{2}$ (depending on salinity) presented by Rudels (2011), although it is discussed there that this heat loss appears rather small for such high latitudes. 
Ocean Sci. Discuss., https://doi.org/10.5194/os-2017-98

Manuscript under review for journal Ocean Sci.

Discussion started: 15 December 2017

(c) Author(s) 2017. CC BY 4.0 License.

Discussions

(c) (i)

We check the influence of the spatial coverage of C-GLORSv7 data on the transport estimates by choosing only one reanalysis transport point for each observational point (i.e. reducing C-GLORSv7 spatial coverage) and interpolating horizontally between them to the full cross-section grid. We conduct this analysis for Davis Strait, because the incorporation of model data into OBS is limited to the upper $100 \mathrm{~m}$ due to sufficient observational coverage in the remainder of Davis Strait (Tsubouchi et al., 2017b). We obtain a volume transport estimate of $-2.3 \pm 0.6 \mathrm{~Sv}$, which compares well with the estimate obtained from full C-GLORSv7 resolution (- $2.4 \pm 0.5 \mathrm{~Sv}$, derived from summing over the full cross-section). When reducing the resolution even further to half the observational points, the volume export becomes smaller $(-1.6 \pm 1.4 \mathrm{~Sv})$ than the original estimate. This suggests that the results quickly become rather sensitive to the exact choice of points if the resolution is further reduced. Whether the resolution of observations and model points is sufficient in a strait presumably depends on the heterogeneity of transports through each strait.

\subsection{Fram Strait}

The average volume export through Fram Strait as estimated from C-GLORSv7 (- $2.2 \pm 0.9 \mathrm{~Sv}$ ) is larger than the observationbased estimate (- $1.1 \pm 1.2 \mathrm{~Sv}$, see Tab. 1) although the values agree within their respective temporal variability ranges. The temperature transport is smaller ( $45 \pm 11 \mathrm{TW}, \mathrm{C}$-GLORSv7) than in OBS (58 $\pm 17 \mathrm{TW})$ throughout the whole study period

15 (see Fig. 2). Other model-based estimates of Fram Strait volume exports are similar to our C-GLORSv7 estimates: Fieg et al. (2010) calculated a transport of $-2.0 \pm 1.26 \mathrm{~Sv}$ based on a $1 / 12^{\circ}$ resolution model with 50 vertical levels and Zuo et al. (2011) reported $-2.5 \pm 0.5 \mathrm{~Sv}$ for the UR025.1 averaged over $1987-2004$, both estimates being closer to the C-GLORSv7 estimate than to the observation-based one. For the control experiment, we obtain - $1.8 \pm 0.8 \mathrm{~Sv}$ (see Tab. 1) which is in perfect agreement with Zuo et al. (2011) who report $-1.8 \pm 0.5 \mathrm{~Sv}$ for their non-assimilating experiment.

20 More interesting than the total transport through Fram Strait are the contributions from the inflowing West Spitzbergen Current (WSC, east of $5^{\circ} \mathrm{E}$ or $\mathrm{d}=550$ to $685 \mathrm{~km}$ in Fig. 5) in the eastern part of the strait, and the East Greenland Current (EGC, $6.5^{\circ}$ $\mathrm{W}$ to $2^{\circ} \mathrm{W}$ or $\mathrm{d}=305$ to $400 \mathrm{~km}$ ) on the western end of the deep basin. In OBS the WSC branch transports $6.4 \pm 0.9 \mathrm{~Sv}$ (Fig. 1) of relatively warm water $\left(1.0 \pm 0.2{ }^{\circ} \mathrm{C}\right)$ northwards, resulting in a temperature transport of $67 \pm 12 \mathrm{TW}$. In the reanalysis, the currents in this branch are weaker, transporting only $5.3 \pm 1.0 \mathrm{~Sv}$ of $0.9 \pm 0.1{ }^{\circ} \mathrm{C}$ warm water. The temperature transport is therefore smaller in the reanalysis $(48 \pm 11 \mathrm{TW})$ in this branch. The smaller northward volume transport is mainly due to the core of the WSC to the very East of Fram Strait (east of $8.2^{\circ} \mathrm{E}$ or $\mathrm{d}=616 \mathrm{~km}$ ) being weaker in the reanalysis $(0.7 \pm 0.2 \mathrm{~Sv}$, Fig. 1) than in OBS (1.6 $\pm 0.4 \mathrm{~Sv})$. Based on the moored array in the WSC, Beszczynska-Möller et al. (2012) report a longterm $(1997-2010)$ average volume transport of $6.6 \pm 0.4 \mathrm{~Sv}$ (with a contribution of $1.8 \pm 0.1 \mathrm{~Sv}$ from the core of the WSC), which is very close to the observation-based estimate from our study.

30 For the EGC, we calculate a southward flow $(-6.1 \pm 1.2 \mathrm{~Sv})$ of $-0.02 \pm 0.10{ }^{\circ} \mathrm{C}$ water, or $-3 \pm 6 \mathrm{TW}$ temperature transport for OBS. For the reanalysis, the volume export is again weaker $(-4.6 \pm 0.9 \mathrm{~Sv})$. The temperature transport is slightly positive, 
Ocean Sci. Discuss., https://doi.org/10.5194/os-2017-98

Manuscript under review for journal Ocean Sci.

Discussion started: 15 December 2017

(c) Author(s) 2017. CC BY 4.0 License.

Discussions

(c) (i)

although with a high temporal variability $(1 \pm 4 \mathrm{TW})$, which can be attributed to the variability in volume transports as the average temperature in this branch is fairly constant $\left(-0.00 \pm 0.06{ }^{\circ} \mathrm{C}\right)$. In the reanalysis, the southward current is stronger in the upper $100 \mathrm{~m}$, but is limited to a narrower region overall, resulting in a weaker volume export. Data-assimilation affects the strength of the two branches, making them stronger compared to the control experiment (WSC: $2.4 \pm 1.0 \mathrm{~Sv}, \mathrm{EGC}$ : $-3.1 \pm 1.0$

$5 \mathrm{~Sv}$ ). In contrast to Davis Strait, the assimilating reanalysis experiment exhibits a stronger horizontal temperature gradient than the control experiment in the upper $800 \mathrm{~m}$, which implies higher velocities in the upper ocean. The agreement with the observation-based estimate is also better for the temperature distribution in Fram Strait in the assimilating experiment compared to the control.

Even though there are several moorings in Fram Strait (see Fig. 4a), some of the instruments failed to record data during the

10 study period (see supporting information of Tsubouchi et al., 2017b). This is especially true for the easternmost part of Fram Strait (core of the WSC), the eastern boundary of the EGC and the upper ocean. The disagreement between the reanalysis and the observation-based velocities is largest in those regions, as is the temperature disagreement in the upper ocean.

Our results for WSC and EGC transports are qualitatively in line with Fieg et al. (2010) who pointed out that many ice-ocean models have weaker volume and temperature imports and exports in Fram Strait compared to observation-based estimates.

15 They attributed the underrepresentation of Fram Strait currents and temperature transports to the recirculation, which in the models occurs further south than observed. Fahrbach et al. (2001) estimated that $2.6 \pm 0.1 \mathrm{~Sv}$ are transported westward between $78.50^{\circ} \mathrm{N}$ and $79^{\circ} \mathrm{N}$. The representation of the recirculation in ocean models is also highly dependent on the horizontal resolution, as Fieg et al. (2010) discuss that their $1 / 4^{\circ}$ model does not capture the recirculation, whereas their $1 / 12^{\circ}$ model does. This is further supported by Hattermann et al. (2016), who find that mesoscale eddies contribute significantly to the

20 recirculation, which is especially strong during winter and spring, when eddies divert the WSC westward, just North of the moored array. In conclusion, it seems likely that the horizontal resolution of C-GLORSv7 (1/4 $\left.{ }^{\circ}\right)$ is too low to capture the eddydriven recirculation, resulting in weaker volume and temperature transports in both branches.

\subsection{Barents Sea Opening}

The volume transport calculated from the reanalysis fields is greater (3.4 $\pm 1.1 \mathrm{~Sv}$, C-GLORSv7) than the observation-based estimate $(2.3 \pm 1.2 \mathrm{~Sv}, \mathrm{Tab} .1)$ throughout the entire study period. The temperature transport through the BSO is larger in the reanalysis $(89 \pm 27 \mathrm{TW})$ compared to the observation-based estimate $(63 \pm 32 \mathrm{TW})$ during almost the entire period (Fig. 2). Comparing C-GLORSv7 to $\mathrm{OBS}$, we find similar cross-section average temperatures $\left(4.5 \pm 2.8^{\circ} \mathrm{C}\right.$ in $\mathrm{OBS}, 4.3 \pm 2.3{ }^{\circ} \mathrm{C}$ in $\mathrm{C}$ GLORSv7), so the higher volume transport of $3.4 \mathrm{~Sv}$ compared to $2.3 \mathrm{~Sv}$ likely drives higher $\mathrm{F}_{\theta}$ in the reanalysis since the temperatures are greater than zero throughout the year in the majority of the BSO. The only region where temperatures are

30 negative during the winter months is North of Bear Island, but the average volume transports are small there $(0.04 \pm 0.20 \mathrm{~Sv}$ from C-GLORSv7), having little effect $(0.8 \pm 0.8 \mathrm{TW})$ on the overall temperature transport through the strait. 
Ocean Sci. Discuss., https://doi.org/10.5194/os-2017-98

Manuscript under review for journal Ocean Sci.

Discussion started: 15 December 2017

(c) Author(s) 2017. CC BY 4.0 License.

Discussions

(c) (i)

The cross-sections of differences in $\mathrm{F}_{\theta}$ between the reanalysis and observation-based data clearly resemble the pattern of the $F_{V}$ differences (Fig. 5). This is reflected in a high pattern correlation (83\%) between the difference fields of $F_{V}$ and $F_{\theta}$. This further supports our argument that velocity rather than temperature patterns (the pattern correlation between temperature difference and $\mathrm{F}_{\theta}$ difference is only $3 \%$ ) drive the discrepancy in $\mathrm{F}_{\theta}$.

5 Both the temperature and volume transports are greater in C-GLORSv7 and in C-GLORSv7 control compared to OBS, by approximately 1-2 Sv and roughly 10-30 TW throughout the study period. The difference between C-GLORSv7 (89 $\pm 27 \mathrm{TW}$ and $3.4 \pm 1.1 \mathrm{~Sv})$ and $\mathrm{v} 7 \mathrm{control}(75 \pm 22 \mathrm{TW}$ and $3.3 \pm 1.0 \mathrm{~Sv})$ is similar to the findings presented by Zuo et al. (2011). They also report a $10 \mathrm{TW}$ difference between the full $(82.8 \pm 8.9 \mathrm{TW})$ and non-assimilating $(73.2 \pm 6.8 \mathrm{TW})$ experiments, both referenced to $0{ }^{\circ} \mathrm{C}$. However, they attribute this to the higher volume transport in the full experiment $(3.4 \pm 0.3 \mathrm{~Sv}$ compared

10 to $3.0 \pm 0.2 \mathrm{~Sv}$ ). In our case the higher temperature transport in the full experiment can be related to higher cross-section average temperatures $\left(4.3 \pm 0.5^{\circ} \mathrm{C}\right)$ compared to the control experiment $\left(3.9 \pm 0.6^{\circ} \mathrm{C}\right)$ since the volume transport is almost the same in both experiments. In the BSO, data assimilation increases the agreement in the temperature cross-sections between the reanalysis and OBS. The improvement in temperature distributions is not surprising, since both OBS and C-GLORS incorporate vessel based CTD data from several cruises in this strait.

15 Roughly one third of the discrepancy in BSO volume transports between the reanalysis and observation-based data can be attributed to the individual representation of the flow in the Bear Island Channel (BIC, $\mathrm{d}=360-470 \mathrm{~km}$ in Fig. 5 or $74.3^{\circ} \mathrm{N}$ to $73.4^{\circ} \mathrm{N}$ ). As discussed by Smedsrud et al. (2010), Fv through the BSO south of Bear Island consists of an inflowing branch of roughly $3.2 \mathrm{~Sv}$ and an outflowing branch in the BIC. From the one year of OBS, we estimate the strength of this outflowing current to be $-0.34 \pm 0.60 \mathrm{~Sv}$ (Fig. 1), which is considerably smaller than the previous estimate of - $1.2 \mathrm{~Sv}$ derived from insitu observations between 09/1978 - 01/1979 (Blindheim, 1989). This weaker export might, at least partly, be explained by the inter-annual variability of the BSO flow driven by variations in the local wind field (Ingvaldsen, 2005). In contrast to OBS and literature estimates the C-GLORSv7 volume flow in the BIC is eastward $(0.32 \pm 0.26 \mathrm{~Sv})$ throughout the entire study period, except for a negligible export of $<2 \mathrm{mSv}$ in December 2005. In both the assimilating and the control reanalysis experiments the average volume transport is positive in the BIC. On a side note, the velocity cross-sections based on OBS reveal an eastward transport in parts of the BIC between January and March, as well as in September and June. This leads to a high temporal variability of the OBS FV estimate through the BIC. Ingvaldsen (2005) also mentioned that Arctic inflow in this region is to be expected during winter. Averaged over the study period, the BIC contributes $-7 \pm 13$ TW to the overall heat flux in OBS, whereas the contribution is positive $(6 \pm 4 \mathrm{TW})$ in C-GLORSv7. $\mathrm{F}_{\mathrm{V}}$ and $\mathrm{F}_{\theta}$ through the remaining BSO south of Bear Island are $2.4 \pm 0.9 \mathrm{~Sv}$ and $71 \pm 31 \mathrm{TW}(\mathrm{OBS})$. In C-GLORSv7 the transports are $3.0 \pm 0.8 \mathrm{~Sv}$ and $79 \pm 23 \mathrm{TW}$. We estimate that $28 \%$ of the discrepancy in $\mathrm{F}_{\mathrm{V}}$ and $21 \%$ of the discrepancy in $\mathrm{F}_{\theta}$ are attributable to the BIC, despite the fact that it covers only $15 \%$ of the BSO cross-section area. 
Ocean Sci. Discuss., https://doi.org/10.5194/os-2017-98

Manuscript under review for journal Ocean Sci.

Discussion started: 15 December 2017

(c) Author(s) 2017. CC BY 4.0 License.

\subsection{Bering Strait}

Disagreement is detected in the net $\mathrm{F}_{\mathrm{V}}$ estimates $(1.0 \pm 0.6 \mathrm{~Sv}$ from C-GLORSv7 versus $0.7 \pm 0.7 \mathrm{~Sv}$ from OBS, Tab. 1) through Bering Strait, although the values lie within each other's temporal variability range. The temperature transport estimates are $2 \pm 10 \mathrm{TW}$ (OBS) and $6 \pm 14 \mathrm{TW}$ (C-GLORSv7). The observed volume transport through Bering Strait was low during 2005, while transports in more recent years were closer to $1 \mathrm{~Sv}$ (Woodgate et al., 2012).

The high temporal variability of cross-section average temperatures (December to February: $-1.8 \pm 0.0^{\circ} \mathrm{C}$ from OBS, $-1.2 \pm$ $0.2{ }^{\circ} \mathrm{C}$ from C-GLORSv7, June to August: $1.3 \pm 1.3{ }^{\circ} \mathrm{C}$ from OBS and $2.7 \pm 1.4{ }^{\circ} \mathrm{C}$ from C-GLORSv7) and volume transports (December to February: $0.3 \pm 0.8 \mathrm{~Sv}$ from OBS and $0.7 \pm 0.6 \mathrm{~Sv}$ from C-GLORSv7, June to August: $1.3 \pm 0.2$ from OBS and $1.4 \pm 0.1 \mathrm{~Sv}$ from C-GLORSv7) results in a high variability in temperature transports. High temporal variability of Bering

10 Strait average temperature and volume transports has already been reported by Woodgate et al. (2005). The temperature transport is negative between December and May in C-GLORS (in both reanalysis experiments), due to negative average temperatures and positive volume transports. Likewise, between January and June for OBS. Volume transports are higher during the study period in C-GLORS (in both experiments). Combined with higher average temperatures between June and August, $F_{\theta}$ is also higher in the reanalysis during the summer months. For the rest of the study period, discrepancies in

15 temperature and velocities balance each other, so that monthly $\mathrm{F}_{\theta}$ estimates are close in C-GLORS and the observation-based data (Fig. 2).

During the summer months June to August, the vertical distribution of temperatures is relatively homogeneous in OBS, whereas the ocean is clearly stratified in the reanalysis (see Fig. 7). This is attributed to the fact that the shallowest instruments measuring temperature in this strait are located at $35 \mathrm{~m}$ depth (see Fig. 6 - 7). Woodgate et al. (2010) mentioned the presence

20 of a warm surface layer in Bering Strait during summer and that the average cross-section temperatures are underestimated when using only near-bottom measurements. Therefore, confidence is higher in the Bering Strait temperature distribution derived from C-GLORSv7 than from the mooring-based dataset. During the winter months, the temperature distribution is almost uniform across the strait in both datasets, which is in accordance with Woodgate et al. (2005a), who reported a wellmixed water column during autumn/winter.

25 Data-assimilation in this strait has almost no influence on the volume transport (1.0 $\pm 0.5 \mathrm{~Sv}$ from the control experiment) in the CGLORSv7 reanalysis. Zuo et al. (2011) calculate the Bering Strait volume transport to be $1.3 \pm 0.1 \mathrm{~Sv}$ for both the control experiment and the full UR025.1. They also mention that the small influence of data assimilation is not surprising considering the relatively limited observational coverage.

\section{Conclusion}

30 Summarizing the results from our comparison of the CMCC Global Ocean Physical Reanalysis System (C-GLORS version 7) 
Ocean Sci. Discuss., https://doi.org/10.5194/os-2017-98

Manuscript under review for journal Ocean Sci.

Discussion started: 15 December 2017

(c) Author(s) 2017. CC BY 4.0 License.

Discussions

(c) (i)

with observation-based (OBS) estimates in the Arctic gateways, we first note that the net horizontal volume transport estimates are a factor five smaller in C-GLORSv7 $(-0.03 \pm 0.23 \mathrm{~Sv})$ than in OBS $(-0.15 \pm 0.06 \mathrm{~Sv})$. The average net heat transport into the Arctic Ocean from the two datasets agrees very well and is close to $150 \mathrm{TW}$ (153 \pm 44 TW from the observation-based data and $145 \pm 35$ from C-GLORSv7).

5 Looking in more detail at the comparisons in the individual straits, we find good agreement in Davis Strait volume transports $(-2.3 \pm 0.4 \mathrm{~Sv}$ from C-GLORSv7 versus $-2.1 \pm 0.7 \mathrm{~Sv}$ from OBS), but not for the temperature transport (5 $\pm 4 \mathrm{TW}$ from $\mathrm{C}$ GLORSv7, $29 \pm 10 \mathrm{TW}$ from OBS). The difference in the temperature transport is related to a small volume export in the reanalysis in the warm eastern Davis Strait (east of $d=200 \mathrm{~km}$ in Fig. 3a). In contrast, currents are northward in this area in OBS, in accordance with Beszczynska-Möller et al. (2011). Compared to the full reanalysis resolution, the volume transport

10 estimates for Davis Strait are not significantly altered when reducing the horizontal resolution of C-GLORSv7 data to the instrument locations. However, if the reanalysis resolution is reduced even further, the estimates start to differ notably $(-1.6 \pm$ 1.4 Sv when using only half of the instrument locations in the reanalysis).

The volume and temperature transports through the Canadian Straits (Lancaster Sound, Nares Strait and Hell Gate/Cardigan Strait) are estimated to have been $-1.9 \pm 0.3 \mathrm{~Sv}$ and $8 \pm 1 \mathrm{TW}$ during our study period from September 2005 to August 2006 , based on C-GLORSv7. The temperature transport is higher than in Davis Strait $(5 \pm 4 \mathrm{TW})$. This would imply an unrealistic lateral oceanic energy divergence in Baffin Bay, which is why we have more confidence in the temperature transport through Davis Strait from the observation-based data $(29 \pm 10 \mathrm{TW})$ than from the reanalysis.

We find weaker inflowing and outflowing currents in Fram Strait in the reanalysis compared to the observation-based estimate. The strength of the northward West Spitzbergen Current in the eastern part of Fram Strait is about $1 \mathrm{~Sv}$ greater in the observation-based data $(6.4 \pm 0.9 \mathrm{~Sv})$ compared to the reanalysis $(5.3 \pm 1.0 \mathrm{~Sv}, \mathrm{C}-\mathrm{GLORSv})$. The export in the East Greenland Current at the western end of deep Fram Strait is - 6.1 $\pm 1.2 \mathrm{~Sv}$ in the observation-based data, which is again larger than in the reanalysis (- $4.6 \pm 0.9 \mathrm{~Sv}, \mathrm{C}-\mathrm{GLORSv} 7)$. The agreement in the strength of those two branches is better in C-GLORS v7 compared to the control experiment, which seems to be related to a stronger horizontal temperature gradient in the assimilating experiment.

25 For the Barents Sea Opening, our transport estimates from C-GLORSv7 (3.4 $\pm 1.1 \mathrm{~Sv}$ and $89 \pm 27$ TW) are greater than in the observation-based estimate $(2.3 \pm 1.2 \mathrm{~Sv}$ and $63 \pm 32 \mathrm{TW})$. The greater volume and temperature transports are at least partly due to currents in the Bear Island Channel flowing eastwards in the reanalysis (in both reanalysis versions with and without data assimilation), whereas they are westward in OBS. This observation-based export is qualitatively in line with previous descriptions of Barents Sea Opening currents (Smedsrud et al., 2010), albeit the transport through the Bear Island Channel is 30 weaker $(-0.34 \pm 0.60 \mathrm{~Sv})$ in our study than the 1.2 Sv reported by Blindheim (1989). Based on the C-GLORSv7 reanalysis, we estimate that the flow north of Bear Island is small but with a high temporal variability $(0.04 \pm 0.20 \mathrm{~Sv}$ and $0.8 \pm 0.8 \mathrm{TW})$. 
Ocean Sci. Discuss., https://doi.org/10.5194/os-2017-98

Manuscript under review for journal Ocean Sci.

Discussion started: 15 December 2017

(c) Author(s) 2017. CC BY 4.0 License.

In this strait, data assimilation improves the agreement between the observation-based data and C-GLORS concerning the temperature distribution. This is not surprising, since vessel-based hydrographic observations are incorporated in both datasets. Finally, the observation-based estimate of Bering Strait volume transports is significantly weaker in the observation-based dataset $(0.7 \pm 0.7 \mathrm{~Sv})$ compared to the reanalysis $(1.0 \pm 0.6 \mathrm{~Sv}, \mathrm{C}-\mathrm{GLORSv} 7)$.

5 We find that the disagreement between the reanalysis and OBS is often associated with regions where in-situ observations are lacking (either because of the absence of instruments or due to instrumental failure during the study period). This is evident in Bering Strait during summer, when the observation-based dataset shows no sign of stratification due to the lack of measurements close to the surface. Similarly, the region North of Bear Island where there are no in-situ observations shows discrepancies in the Barents Sea Opening cross-sections, as does the unobserved Belgica Bank in Fram Strait. Even though

10 most parts of Fram Strait and Davis Strait have quite a high instrumental coverage, some of the regions were poorly observed during the study period due to instrumental failures (see supporting information of Tsubouchi et al., 2017b). The eastern boundary of the East Greenland Current and the very East of Fram Strait, but also close to Baffin Island in Davis Strait are examples where the discrepancies in the velocity cross-sections are co-located with sparse data recording during the study period. Both the reanalysis and observation-based dataset would benefit from additional observations, but the Arctic Gateways,

15 especially close to the sea surface, are very challenging and expensive to observe (Beszczynska-Möller et al., 2011). We therefore hope that our study will be helpful in the planning of upcoming reanalysis products and future additions to the observational network in the Arctic Ocean.

In conclusion, both the reanalysis and the observation-based dataset have their advantages and disadvantages. Clearly, the reanalysis provides an important source of information about the state of the ocean where observations are lacking, for example

20 North of the Arctic Gateways. We therefore recommend considering volume and temperature transports as well as velocity and temperature distributions from an ocean reanalysis and in-situ observations where the latter are available using comparative tools like the ones presented in this study. From this comparison, one can then infer the reliability of the reanalysis product for climate studies in data-sparse regions. The present study is also a demonstration of how observation-based data could be used routinely by reanalysis producers to assess the performance of their products in the Arctic. We plan to compare C-GLORS for

25 a longer time period (2004 - 2010) as soon as the corresponding observation-based data become available. This comparison will give insight into discrepancies between the two datasets concerning the seasonal cycles and temporal variability of temperature, velocities and temperature flux densities. 
Ocean Sci. Discuss., https://doi.org/10.5194/os-2017-98

Manuscript under review for journal Ocean Sci.

Discussion started: 15 December 2017

(c) Author(s) 2017. CC BY 4.0 License.

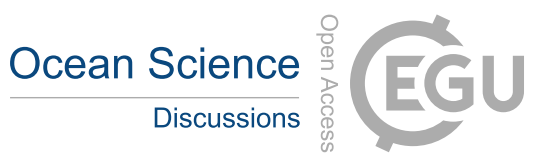

(c) (i)

\section{Data Availability}

The observation-based data are available through PANGAEA (Tsubouchi et al., 2017a). The C-GLORS v5 and v7 data can be obtained from CMCC upon registration at http://c-glors.cmcc.it/.

\section{Supplement link}

5 The conclusions presented in this paper are supported by the figures and tables in the main text. Additional figures supporting the methods can be found in the supplementary material.

\section{Author Contribution}

All authors contributed significantly to this study and to the preparation of this manuscript. Marianne Pietschnig wrote the code for this study and prepared the manuscript with inputs from all authors. Michael Mayer and Leopold Haimberger provided

10 essential expertise on the coupled atmosphere-sea ice-ocean system and how to best analyse the results. Sebastian Stichelberger helped with the preparation of figures. Andrea Storto provided expert knowledge on the ocean reanalysis and Takamasa Tsubouchi on the observation-based dataset as well as on the physical oceanography of the Arctic.

\section{Competing Interests}

The authors declare that they have no conflict of interest.

\section{10. Acknowledgements}

This study was funded by the Austrian Science Fund project P28818 and by ERA-CLIM2 (EU FP7 grant No. 607029). Takamasa Tsubouchi's involvement was supported by the EU's Horizon 2020 Marie Skłodowska-Curie grant agreement No. 652757. The production of C-GLORS is funded through the Copernicus Marine Environment Monitoring Service (CMEMS) of the Copernicus European Union Programme. 
Ocean Sci. Discuss., https://doi.org/10.5194/os-2017-98

Manuscript under review for journal Ocean Sci.

Discussion started: 15 December 2017

(c) Author(s) 2017. CC BY 4.0 License.

\section{References}

Årthun, M., Eldevik, T., Smedsrud, L. H., Skagseth, $\varnothing$. and Ingvaldsen, R. B.: Quantifying the Influence of Atlantic Heat on Barents Sea Ice Variability and Retreat*, J. Clim., 25(13), 4736-4743, doi:10.1175/JCLI-D-11-00466.1, 2012.

Bacon, S., Aksenov, Y., Fawcett, S. and Madec, G.: Arctic mass, freshwater and heat fluxes: methods and modelled seasonal variability, Philos. Trans. R. Soc. Math. Phys. Eng. Sci., 373(2052), 20140169, doi:10.1098/rsta.2014.0169, 2015.

Balmaseda, M. A., Mogensen, K. and Weaver, A. T.: Evaluation of the ECMWF ocean reanalysis system ORAS4, Q. J. R. Meteorol. Soc., 139(674), 1132-1161, doi:10.1002/qj.2063, 2013.

Bernard, B., Madec, G., Penduff, T., Molines, J.-M., Treguier, A.-M., Le Sommer, J., Beckmann, A., Biastoch, A., Böning, C., Dengg, J., Derval, C., Durand, E., Gulev, S., Remy, E., Talandier, C., Theetten, S., Maltrud, M., McClean, J. and De

10 Cuevas, B.: Impact of partial steps and momentum advection schemes in a global ocean circulation model at eddy-permitting resolution, Ocean Dyn., 56(5-6), 543-567, doi:10.1007/s10236-006-0082-1, 2006.

Beszczynska-Möller, A., Woodgate, R., Lee, C., Melling, H. and Karcher, M.: A Synthesis of Exchanges Through the Main Oceanic Gateways to the Arctic Ocean, Oceanography, 24(3), 82-99, doi:10.5670/oceanog.2011.59, 2011.

Beszczynska-Möller, A., Fahrbach, E., Schauer, U. and Hansen, E.: Variability in Atlantic water temperature and transport at the entrance to the Arctic Ocean, 1997-2010, ICES J. Mar. Sci., 69(5), 852-863, doi:10.1093/icesjms/fss056, 2012.

Blindheim, J.: Cascading of Barents Sea bottom water into the Norwegian Sea, Rapp P-V 693 Réun Cons Int Explor Mer, 188, 1989.

Bouillon, S., Morales Maqueda, M. Á., Legat, V. and Fichefet, T.: An elastic-viscous-plastic sea ice model formulated on Arakawa B and C grids, Ocean Model., 27(3-4), 174-184, doi:10.1016/j.ocemod.2009.01.004, 2009.

20 Burgard, C. and Notz, D.: Drivers of Arctic Ocean warming in CMIP5 models, Geophys. Res. Lett., 44(9), 4263-4271, doi:10.1002/2016GL072342, 2017.

Carmack, E. C., Yamamoto-Kawai, M., Haine, T. W. N., Bacon, S., Bluhm, B. A., Lique, C., Melling, H., Polyakov, I. V., Straneo, F., Timmermans, M.-L. and Williams, W. J.: Freshwater and its role in the Arctic Marine System: Sources, disposition, storage, export, and physical and biogeochemical consequences in the Arctic and global oceans, J. Geophys. Res. Biogeosciences, 121(3), 675-717, doi:10.1002/2015JG003140, 2016.

Comiso, J. C., Parkinson, C. L., Gersten, R. and Stock, L.: Accelerated decline in the Arctic sea ice cover, Geophys. Res. Lett., 35(1), doi:10.1029/2007GL031972, 2008.

Curry, B., Lee, C. M. and Petrie, B.: Volume, Freshwater, and Heat Fluxes through Davis Strait, 2004-05*, J. Phys. Oceanogr., 41(3), 429-436, doi:10.1175/2010JPO4536.1, 2011.

30 Curry, B., Lee, C. M., Petrie, B., Moritz, R. E. and Kwok, R.: Multiyear Volume, Liquid Freshwater, and Sea Ice Transports through Davis Strait, 2004-10*, J. Phys. Oceanogr., 44(4), 1244-1266, doi:10.1175/JPO-D-13-0177.1, 2014.

Dee, D. P., Uppala, S. M., Simmons, A. J., Berrisford, P., Poli, P., Kobayashi, S., Andrae, U., Balmaseda, M. A., Balsamo, G., Bauer, P., Bechtold, P., Beljaars, A. C. M., van de Berg, L., Bidlot, J., Bormann, N., Delsol, C., Dragani, R., Fuentes, M., Geer, A. J., Haimberger, L., Healy, S. B., Hersbach, H., Hólm, E. V., Isaksen, L., Kållberg, P., Köhler, M., Matricardi, M., 35 McNally, A. P., Monge-Sanz, B. M., Morcrette, J.-J., Park, B.-K., Peubey, C., de Rosnay, P., Tavolato, C., Thépaut, J.-N. and 
Ocean Sci. Discuss., https://doi.org/10.5194/os-2017-98

Manuscript under review for journal Ocean Sci.

Discussion started: 15 December 2017

(C) Author(s) 2017. CC BY 4.0 License.

Vitart, F.: The ERA-Interim reanalysis: configuration and performance of the data assimilation system, Q. J. R. Meteorol. Soc., 137(656), 553-597, doi:10.1002/qj.828, 2011.

Desroziers, G., Berre, L., Chapnik, B. and Poli, P.: Diagnosis of observation, background and analysis-error statistics in observation space, Q. J. R. Meteorol. Soc., 131(613), 3385-3396, doi:10.1256/qj.05.108, 2005.

5 Dickson, R., Rudels, B., Dye, S., Karcher, M., Meincke, J. and Yashayaev, I.: Current estimates of freshwater flux through Arctic and subarctic seas, Prog. Oceanogr., 73(3-4), 210-230, doi:10.1016/j.pocean.2006.12.003, 2007.

Dickson, R. G. B., Meincke, J. and Rhines, P., Eds.: Arctic-subarctic ocean fluxes: defining the role of the northern seas in climate, Springer, Dordrecht., 2008.

Drange, H., Gerdes, R., Gao, Y., Karcher, M., Kauker, F. and Bentsen, M.: Ocean general circulation modelling of the Nordic seas, in Geophysical Monograph Series, vol. 158, pp. 199-219, American Geophysical Union, Washington, D. C., 2005.

Fahrbach, E., Meincke, J., Østerhus, S., Rohardt, G., Schauer, U., Tverberg, V. and Verduin, J.: Direct measurements of volume transports through Fram Strait, Polar Res., 20(2), 217-224, doi:10.1111/j.1751-8369.2001.tb00059.x, 2001.

Fieg, K., Gerdes, R., Fahrbach, E., Beszczynska-Möller, A. and Schauer, U.: Simulation of oceanic volume transports through Fram Strait 1995-2005, Ocean Dyn., 60(3), 491-502, doi:10.1007/s10236-010-0263-9, 2010.

15 Garric, G. and Parent, L.: Quality Information Document for Global Ocean Reanalysis Products GLOBAL-REANALYSISPHY-001-025, [online] Available from: http://cmems-resources.cls.fr/documents/QUID/CMEMS-GLO-QUID-001-025-011017.pdf, 2017.

Good, S. A., Martin, M. J. and Rayner, N. A.: EN4: Quality controlled ocean temperature and salinity profiles and monthly objective analyses with uncertainty estimates, J. Geophys. Res. Oceans, 118(12), 6704-6716, doi:10.1002/2013JC009067, 2013.

Haine, T. W. N., Curry, B., Gerdes, R., Hansen, E., Karcher, M., Lee, C., Rudels, B., Spreen, G., de Steur, L., Stewart, K. D. and Woodgate, R.: Arctic freshwater export: Status, mechanisms, and prospects, Glob. Planet. Change, 125, 13-35, doi:10.1016/j.gloplacha.2014.11.013, 2015.

Hattermann, T., Isachsen, P. E., von Appen, W.-J., Albretsen, J. and Sundfjord, A.: Eddy-driven recirculation of Atlantic Water

25 in Fram Strait: Eddy-Driven Recirculation in Fram Strait, Geophys. Res. Lett., 43(7), 3406-3414, doi:10.1002/2016GL068323, 2016.

Ingleby, B. and Huddleston, M.: Quality control of ocean temperature and salinity profiles — Historical and real-time data, J. Mar. Syst., 65(1-4), 158-175, doi:10.1016/j.jmarsys.2005.11.019, 2007.

Ingvaldsen, R. B.: Width of the North Cape Current and location of the Polar Front in the western Barents Sea, Geophys. Res.

Ingvaldsen, R. B., Asplin, L. and Loeng, H.: The seasonal cycle in the Atlantic transport to the Barents Sea during the years 1997-2001, Cont. Shelf Res., 24(9), 1015-1032, doi:10.1016/j.csr.2004.02.011, 2004.

Kawasaki, T. and Hasumi, H.: The inflow of Atlantic water at the Fram Strait and its interannual variability, J. Geophys. Res. Oceans, 121(1), 502-519, doi:10.1002/2015JC011375, 2016. 
Ocean Sci. Discuss., https://doi.org/10.5194/os-2017-98

Manuscript under review for journal Ocean Sci.

Discussion started: 15 December 2017

(C) Author(s) 2017. CC BY 4.0 License.

Kwok, R. and Rothrock, D. A.: Decline in Arctic sea ice thickness from submarine and ICESat records: 1958-2008, Geophys. Res. Lett., 36(15), doi:10.1029/2009GL039035, 2009.

Large, W. G. and Yeager, S. G.: The global climatology of an interannually varying air-sea flux data set, Clim. Dyn., 33(23), 341-364, doi:10.1007/s00382-008-0441-3, 2009.

5 Le Traon, P.-Y. and Ogor, F.: ERS-1/2 orbit improvement using TOPEX/POSEIDON: The 2 cm challenge, J. Geophys. Res. Oceans, 103(C4), 8045-8057, doi:10.1029/97JC01917, 1998.

MacLachlan, C., Arribas, A., Peterson, K. A., Maidens, A., Fereday, D., Scaife, A. A., Gordon, M., Vellinga, M., Williams, A., Comer, R. E., Camp, J., Xavier, P. and Madec, G.: Global Seasonal forecast system version 5 (GloSea5): a high-resolution seasonal forecast system: GloSea5: A High-Resolution Seasonal Forecast System, Q. J. R. Meteorol. Soc., 141(689), 10721084, doi:10.1002/qj.2396, 2015.

Madec, G.: NEMO Ocean Engine, Note du Pole de modélisation 27, [online] Available from: http://www.nemoocean.eu/About-NEMO/Reference-manuals/NEMO_book_3.6_STABLE, 2008.

Masina, S., Di Pietro, P., Storto, A. and Navarra, A.: Global ocean re-analyses for climate applications, Dyn. Atmospheres Oceans, 52(1-2), 341-366, doi:10.1016/j.dynatmoce.2011.03.006, 2011.

15 Mayer, M., Haimberger, L., Pietschnig, M. and Storto, A.: Facets of Arctic energy accumulation based on observations and reanalyses 2000-2015, Geophys. Res. Lett., 43(19), 10,420-10,429, doi:10.1002/2016GL070557, 2016.

Melling, H., Agnew, T. A., Falkner, K. K., Greenberg, D. A., Lee, C. M., Münchow, A., Petrie, B., Prinsenberg, S. J., Samelson, R. M. and Woodgate, R. A.: Fresh-Water Fluxes via Pacific and Arctic Outflows Across the Canadian Polar Shelf, in ArcticSubarctic Ocean Fluxes: Defining the Role of the Northern Seas in Climate, edited by R. R. Dickson, J. Meincke, and P. Rhines, pp. 193-247, Springer Netherlands, Dordrecht., 2008.

Münchow, A.: Volume and Freshwater Flux Observations from Nares Strait to the West of Greenland at Daily Time Scales from 2003 to 2009, J. Phys. Oceanogr., 46(1), 141-157, doi:10.1175/JPO-D-15-0093.1, 2016.

Parkinson, C. L. and Comiso, J. C.: On the 2012 record low Arctic sea ice cover: Combined impact of preconditioning and an August storm, Geophys. Res. Lett., 40(7), 1356-1361, doi:10.1002/grl.50349, 2013.

25 Peixoto, J. P. and Oort, A. H.: Physics of climate, American Institute of Physics, New York., 1992.

Penduff, T., Juza, M., Brodeau, L., Smith, G. C., Barnier, B., Molines, J.-M., Treguier, A.-M. and Madec, G.: Impact of global ocean model resolution on sea-level variability with emphasis on interannual time scales, Ocean Sci., 6(1), 269-284, doi:10.5194/os-6-269-2010, 2010.

Peterson, I., Hamilton, J., Prinsenberg, S. and Pettipas, R.: Wind-forcing of volume transport through Lancaster Sound, J.

Geophys. Res. Oceans, 117(C11), doi:10.1029/2012JC008140, 2012.

Reynolds, R. W., Smith, T. M., Liu, C., Chelton, D. B., Casey, K. S. and Schlax, M. G.: Daily High-Resolution-Blended Analyses for Sea Surface Temperature, J. Clim., 20(22), 5473-5496, doi:10.1175/2007JCLI1824.1, 2007.

Rudels, B.: Volume and freshwater transports through the Canadian Arctic Archipelago-Baffin Bay system, J. Geophys. Res., 116, doi:10.1029/2011JC007019, 2011. 
Ocean Sci. Discuss., https://doi.org/10.5194/os-2017-98

Manuscript under review for journal Ocean Sci.

Discussion started: 15 December 2017

(C) Author(s) 2017. CC BY 4.0 License.

Schauer, U. and Beszczynska-Möller, A.: Problems with estimation and interpretation of oceanic heat transport - conceptual remarks for the case of Fram Strait in the Arctic Ocean, Ocean Sci., 5(4), 487-494, doi:10.5194/os-5-487-2009, 2009.

Serreze, M. C., Barrett, A. P., Slater, A. G., Steele, M., Zhang, J. and Trenberth, K. E.: The large-scale energy budget of the Arctic, J. Geophys. Res., 112(D11), doi:10.1029/2006JD008230, 2007.

5 Serreze, M. C., Barrett, A. P., Stroeve, J. C., Kindig, D. N. and Holland, M. M.: The emergence of surface-based Arctic amplification, The Cryosphere, 3(1), 11-19, doi:10.5194/tc-3-11-2009, 2009.

Smedsrud, L. H., Ingvaldsen, R., Nilsen, J. E. $\varnothing$. and Skagseth, ø.: Heat in the Barents Sea: transport, storage, and surface fluxes, Ocean Sci., 6(1), 219-234, doi:10.5194/os-6-219-2010, 2010.

de Steur, L., Hansen, E., Mauritzen, C., Beszczynska-M?ller, A. and Fahrbach, E.: Impact of recirculation on the East

10 Greenland Current in Fram Strait: Results from moored current meter measurements between 1997 and 2009 , Deep Sea Res. Part Oceanogr. Res. Pap., 92, 26-40, doi:10.1016/j.dsr.2014.05.018, 2014.

Storto, A.: Variational quality control of hydrographic profile data with non-Gaussian errors for global ocean variational data assimilation systems, Ocean Model., 104, 226-241, doi:10.1016/j.ocemod.2016.06.011, 2016.

Storto, A. and Masina, S.: C-GLORSv5: an improved multipurpose global ocean eddy-permitting physical reanalysis, Earth 15 Syst. Sci. Data, 8(2), 679-696, doi:10.5194/essd-8-679-2016, 2016a.

Storto, A. and Masina, S.: The CMCC Eddy-permitting Global Ocean Physical Reanalysis (C-GLORS v5, 1980-2014), , doi:10.1594/PANGAEA.857995, 2016b.

Storto, A., Masina, S. and Dobricic, S.: Estimation and Impact of Nonuniform Horizontal Correlation Length Scales for Global Ocean Physical Analyses, J. Atmospheric Ocean. Technol., 31(10), 2330-2349, doi:10.1175/JTECH-D-14-00042.1, 2014.

20 Storto, A., Masina, S., Balmaseda, M., Guinehut, S., Xue, Y., Szekely, T., Fukumori, I., Forget, G., Chang, Y.-S., Good, S. A., Köhl, A., Vernieres, G., Ferry, N., Peterson, K. A., Behringer, D., Ishii, M., Masuda, S., Fujii, Y., Toyoda, T., Yin, Y., Valdivieso, M., Barnier, B., Boyer, T., Lee, T., Gourrion, J., Wang, O., Heimback, P., Rosati, A., Kovach, R., Hernandez, F., Martin, M. J., Kamachi, M., Kuragano, T., Mogensen, K., Alves, O., Haines, K. and Wang, X.: Steric sea level variability (1993-2010) in an ensemble of ocean reanalyses and objective analyses, Clim. Dyn., 1-21, doi:10.1007/s00382-015-2554-9, 252015.

Storto, A., Masina, S. and Navarra, A.: Evaluation of the CMCC eddy-permitting global ocean physical reanalysis system (CGLORS, 1982-2012) and its assimilation components: Evaluation of C-GLORS Global Ocean Reanalysis, Q. J. R. Meteorol. Soc., 142(695), 738-758, doi:10.1002/qj.2673, 2016.

Stroeve, J. C., Kattsov, V., Barrett, A., Serreze, M., Pavlova, T., Holland, M. and Meier, W. N.: Trends in Arctic sea ice extent from CMIP5, CMIP3 and observations, Geophys. Res. Lett., 39(16), doi:10.1029/2012GL052676, 2012.

Tsubouchi, T., Bacon, S., Naveira Garabato, A. C., Aksenov, Y., Laxon, S. W., Fahrbach, E., Beszczynska-Möller, A., Hansen, E., Lee, C. M. and Ingvaldsen, R. B.: The Arctic Ocean in summer: A quasi-synoptic inverse estimate of boundary fluxes and water mass transformation, J. Geophys. Res. Oceans, 117(C1), doi:10.1029/2011JC007174, 2012.

Tsubouchi, T., Bacon, S., Naveira Garabato, A. C., Aksenov, Y., Schauer, U., Beszczynska-Möller, A., Hansen, E. H., de 35 Steur, L., Lee, C., Curry, B. and Ingvaldsen, R.: Pan-Arctic Oceanic volume, heat and freshwater transport time series during 2005 to 2006, link to model results in NetCDF Format., PANGAEA - Data Publ. Earth Environ. Sci., doi:10.1594/PANGAEA.870607, 2017a. 
Ocean Sci. Discuss., https://doi.org/10.5194/os-2017-98

Manuscript under review for journal Ocean Sci.

Discussion started: 15 December 2017

(C) Author(s) 2017. CC BY 4.0 License.

Tsubouchi, T., Bacon, S., Aksenov, Y., Naveira Garabato, A. C., Beszczynska-Möller, A., Hansen, E., de Steur, L., Curry, B. and Lee, C. M.: The Arctic Ocean seasonal cycle: an observation based inverse estimate, J. Phys. Oceanogr., (submitted) [online] Available from: arXiv:1711.10880, 2017b.

Valdivieso, M. and Haines, K.: Global Ocean Physics Reanalysis UR025.4 (1989-2010) as part of the VALue of the RAPID5 WATCH Climate Change programme array (VALOR) project, , doi:10.5285/4bcfa3a4-c7ec-4414-863d-caeceb21f16f, 2013.

Valdivieso, M., Haines, K., Zuo, H. and Lea, D.: Freshwater and heat transports from global ocean synthesis, J. Geophys. Res. Oceans, 119(1), 394-409, doi:10.1002/2013JC009357, 2014.

Woodgate, R., Stafford, K. and Prahl, F.: A Synthesis of Year-Round Interdisciplinary Mooring Measurements in the Bering Strait (1990-2014) and the RUSALCA Years (2004-2011), Oceanography, 28(3), 46-67, doi:10.5670/oceanog.2015.57, 2015.

10 Woodgate, R. A., Aagaard, K. and Weingartner, T. J.: A year in the physical oceanography of the Chukchi Sea: Moored measurements from autumn 1990-1991, Deep Sea Res. Part II Top. Stud. Oceanogr., 52(24-26), 3116-3149, doi:10.1016/j.dsr2.2005.10.016, 2005a.

Woodgate, R. A., Aagaard, K. and Weingartner, T. J.: Monthly temperature, salinity, and transport variability of the Bering Strait through flow, Geophys. Res. Lett., 32(4), doi:10.1029/2004GL021880, 2005b.

15 Woodgate, R. A., Weingartner, T. and Lindsay, R.: The 2007 Bering Strait oceanic heat flux and anomalous Arctic sea-ice retreat, Geophys. Res. Lett., 37(1), doi:10.1029/2009GL041621, 2010.

Woodgate, R. A., Weingartner, T. J. and Lindsay, R.: Observed increases in Bering Strait oceanic fluxes from the Pacific to the Arctic from 2001 to 2011 and their impacts on the Arctic Ocean water column, Geophys. Res. Lett., 39(24), doi:10.1029/2012GL054092, 2012.

20 Yang, C., Masina, S., Bellucci, A. and Storto, A.: The Rapid Warming of the North Atlantic Ocean in the Mid-1990s in an Eddy-Permitting Ocean Reanalysis (1982-2013), J. Clim., 29(15), 5417-5430, doi:10.1175/JCLI-D-15-0438.1, 2016.

Zhang, J. and Rothrock, D. A.: Modeling Global Sea Ice with a Thickness and Enthalpy Distribution Model in Generalized Curvilinear Coordinates, Mon. Weather Rev., 131(5), 845-861, doi:10.1175/15200493(2003)131<0845:MGSIWA>2.0.CO;2, 2003.

25 Zuo, H., Mugford, R. I., Haines, K. and Smith, G. C.: Assimilation impacts on Arctic Ocean circulation, heat and freshwater budgets, Ocean Model., 40(2), 147-163, doi:10.1016/j.ocemod.2011.08.008, 2011. 
Ocean Sci. Discuss., https://doi.org/10.5194/os-2017-98

Manuscript under review for journal Ocean Sci.

Discussion started: 15 December 2017

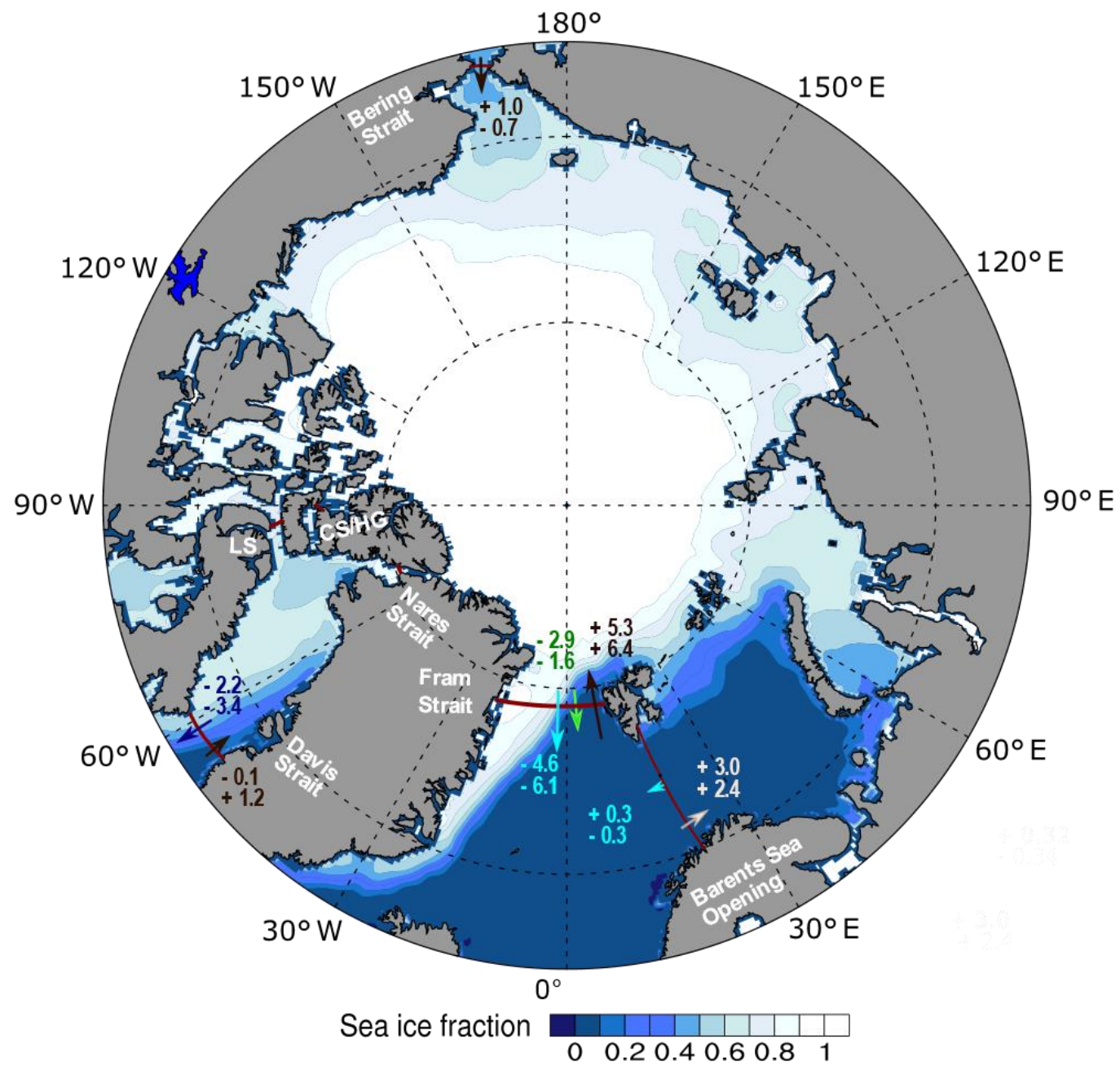

Figure 1: Overview map of the Arctic Ocean, showing the four main gateways (Davis Strait, Fram Strait, the Barents Sea Opening and Bering Strait). The volume transports (in Sv) averaged over the study period 09/2005 - 08/2006 of the main currents through these straits are given for the reanalysis (C-GLROSv7, top value) and below that the observation-based estimate. The location of the Canadian Straits (Nares Strait, Lancaster Sound (LS) and Hell Gate/Cardigan Strait (HG/CS)) are marked. The sea ice fraction (obtained from PIOMAS for our study period from September 2005 to August 2006) is shown in shades of blue (0) to white (1). 
Ocean Sci. Discuss., https://doi.org/10.5194/os-2017-98

Manuscript under review for journal Ocean Sci.

Discussion started: 15 December 2017
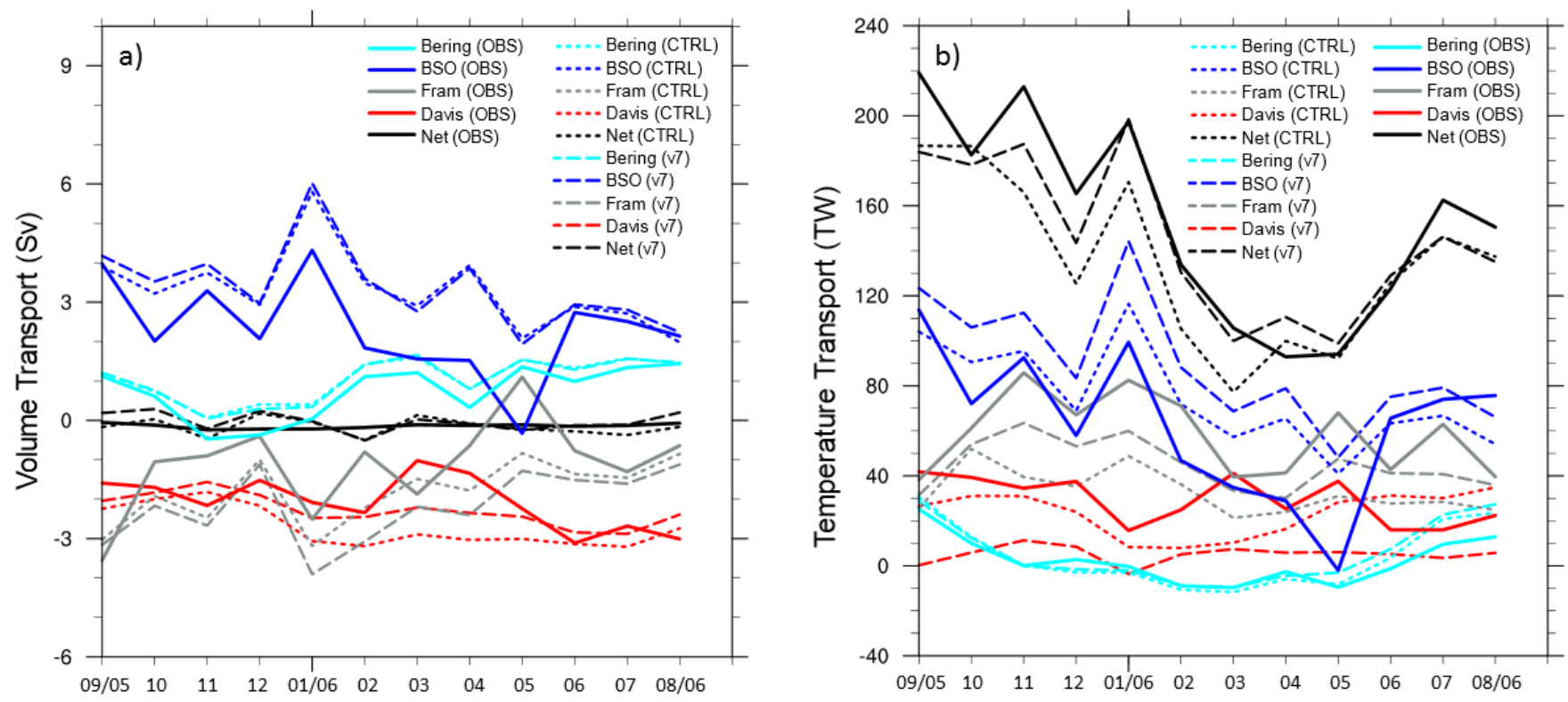

Figure 2: Time series of (a) volume and (b) temperature transports through the individual straits and net transports from the observation-based dataset ("OBS", solid lines) and from the reanalysis C-GLORSv7 ("v7", dashed, control experiment "CTRL", dotted). The study period averages for the observation-based data and the reanalysis are given in Tab. 1. 
Ocean Sci. Discuss., https://doi.org/10.5194/os-2017-98

Manuscript under review for journal Ocean Sci.

Discussion started: 15 December 2017

(c) Author(s) 2017. CC BY 4.0 License.

Discussions

(c) (1)

a) Velocity $(\mathrm{m} / \mathrm{s})$
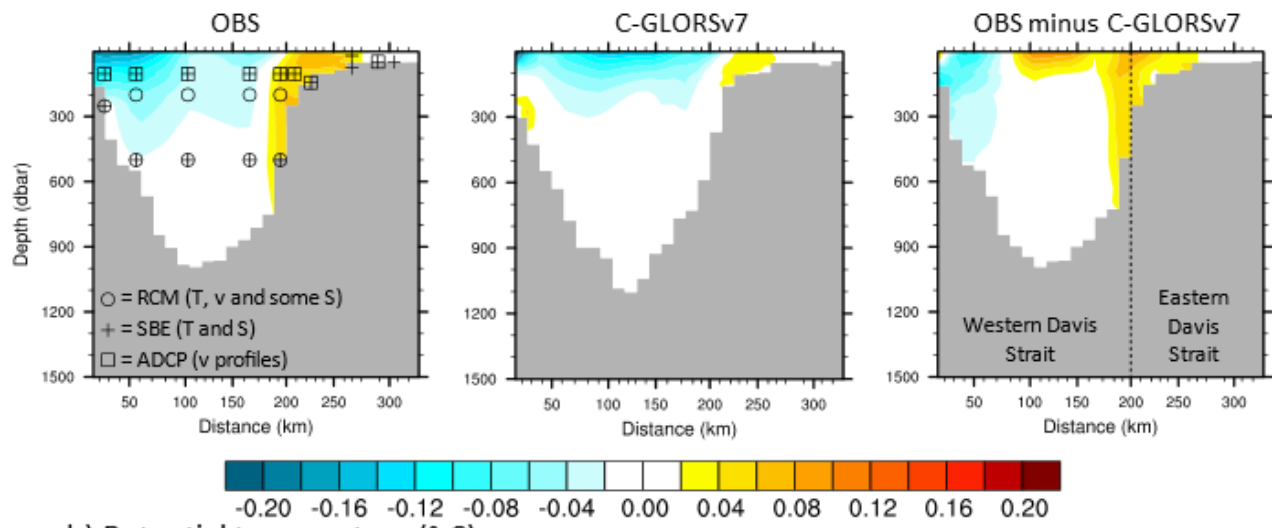

b) Potential temperature $\left({ }^{\circ} \mathrm{C}\right)$
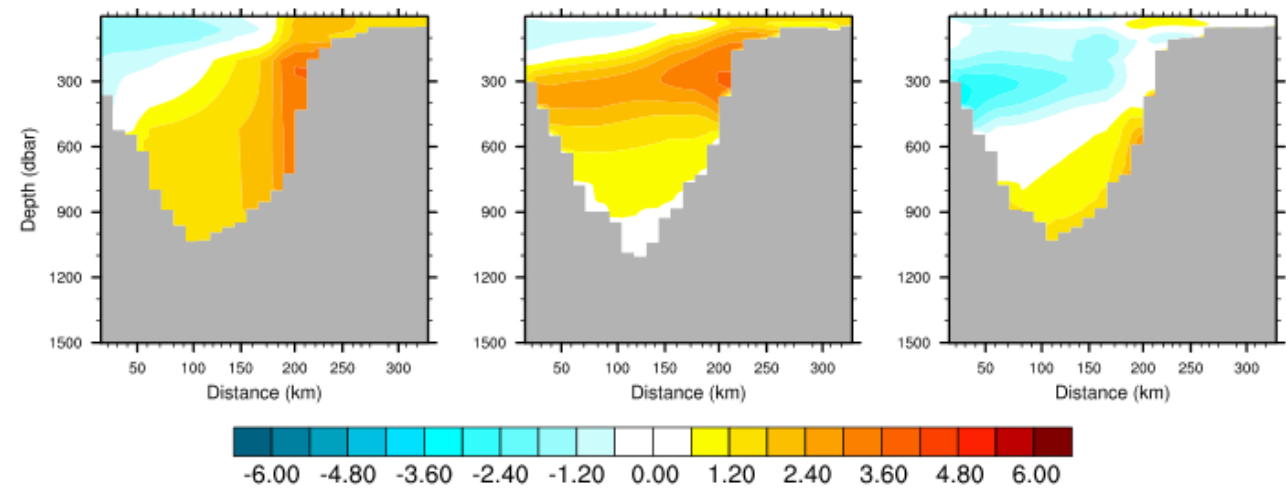

c) Temperature flux density $\left(\mathrm{W} / \mathrm{m}^{2}\right)$
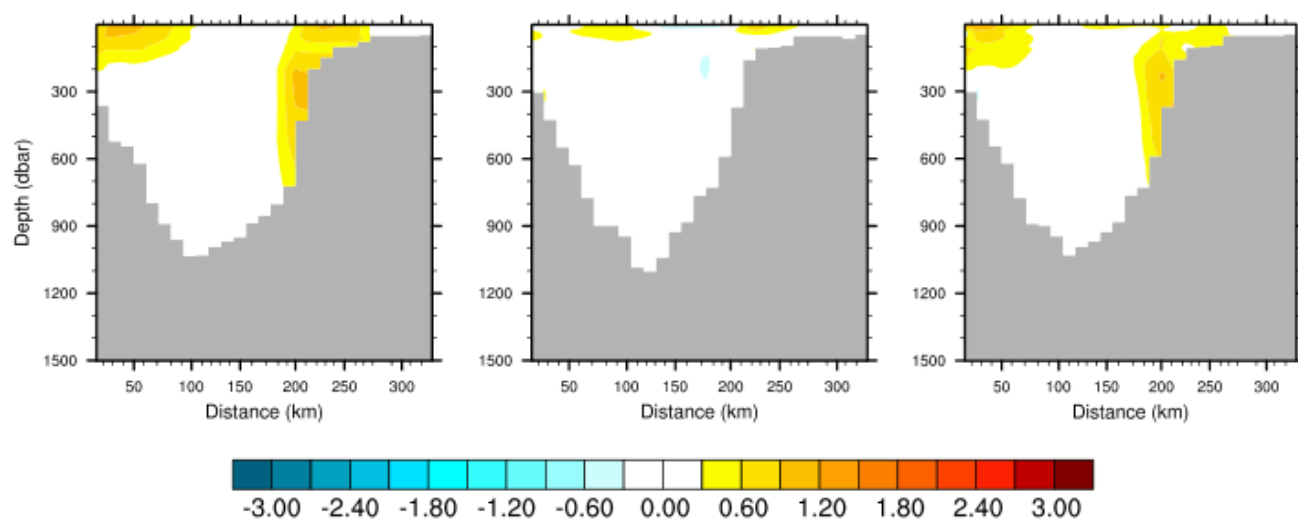

Figure 3a: (a) Velocity in $\mathrm{m} / \mathrm{s}$, (b) potential temperature in ${ }^{\circ} \mathrm{C}$ and (c) temperature flux density in $\mathrm{W} / \mathrm{m}^{2}$ cross-section plots for Davis Strait obtained from the observation-based dataset (OBS), C-GLORS version 7 and the difference between the two. The plots show averages of the fields over the one-year study period. The distance (x-axis) is the great circle distance to a point on the coast of Baffin Island $\left(66.6^{\circ} \mathrm{N}\right.$ and $\left.61.3^{\circ} \mathrm{W}\right)$. Positive velocities signify Arctic inflow and are directed into the paper. The symbols in the observation-based cross-section show the locations of moored instruments in the strait. A combination of two symbols signifies locations of both instrument types. 
Ocean Sci. Discuss., https://doi.org/10.5194/os-2017-98

Manuscript under review for journal Ocean Sci.

Discussion started: 15 December 2017

(c) Author(s) 2017. CC BY 4.0 License.

a) Velocity $(\mathrm{m} / \mathrm{s})$
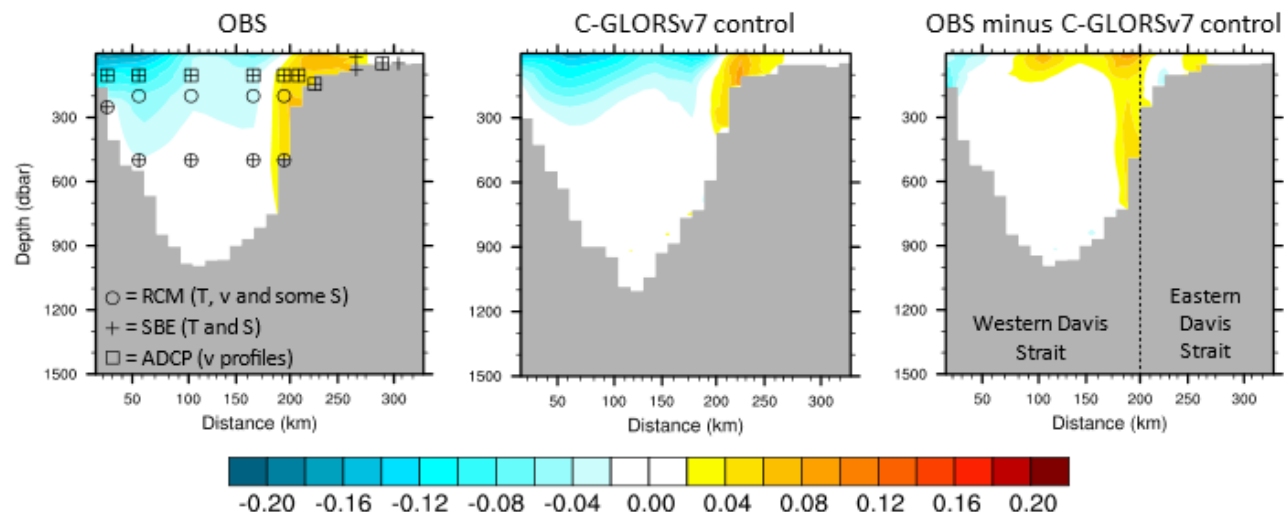

b) Potential temperature $\left({ }^{\circ} \mathrm{C}\right)$
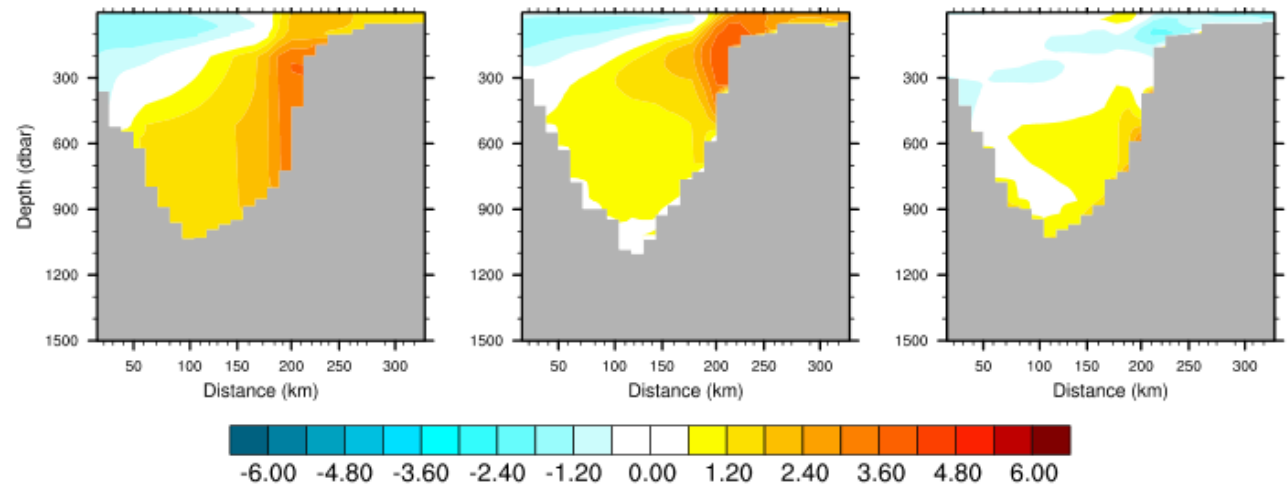

c) Temperature flux density $\left(\mathrm{W} / \mathrm{m}^{2}\right)$
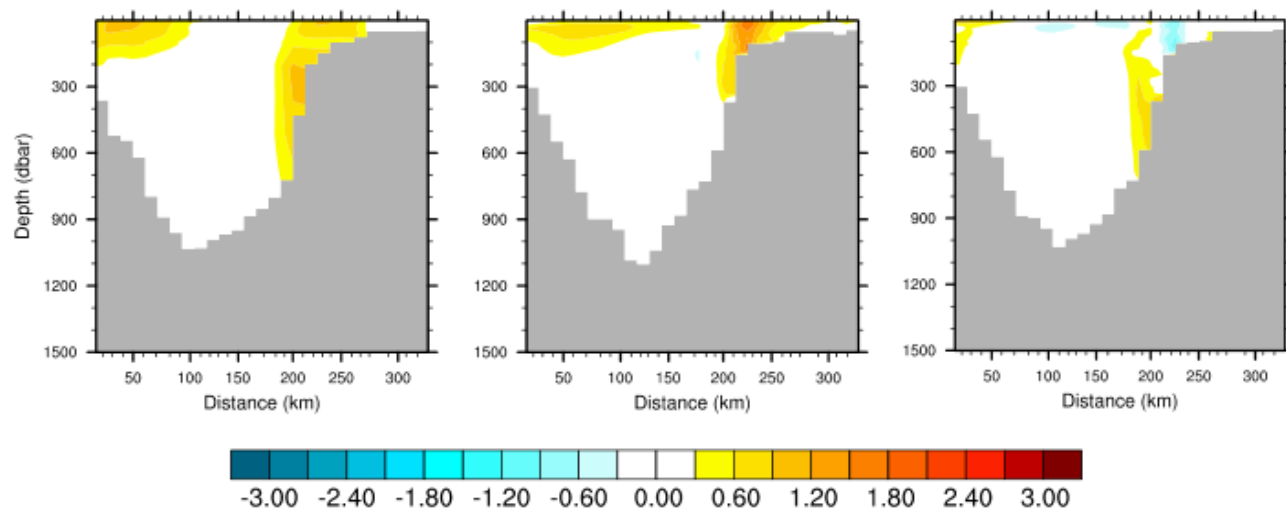

Figure 3b: Same as Figure 3a, but for the control experiment (C-GLORSv7 control). 
Ocean Sci. Discuss., https://doi.org/10.5194/os-2017-98

Manuscript under review for journal Ocean Sci.

Discussion started: 15 December 2017

(c) Author(s) 2017. CC BY 4.0 License.

a) Velocity $(\mathrm{m} / \mathrm{s})$
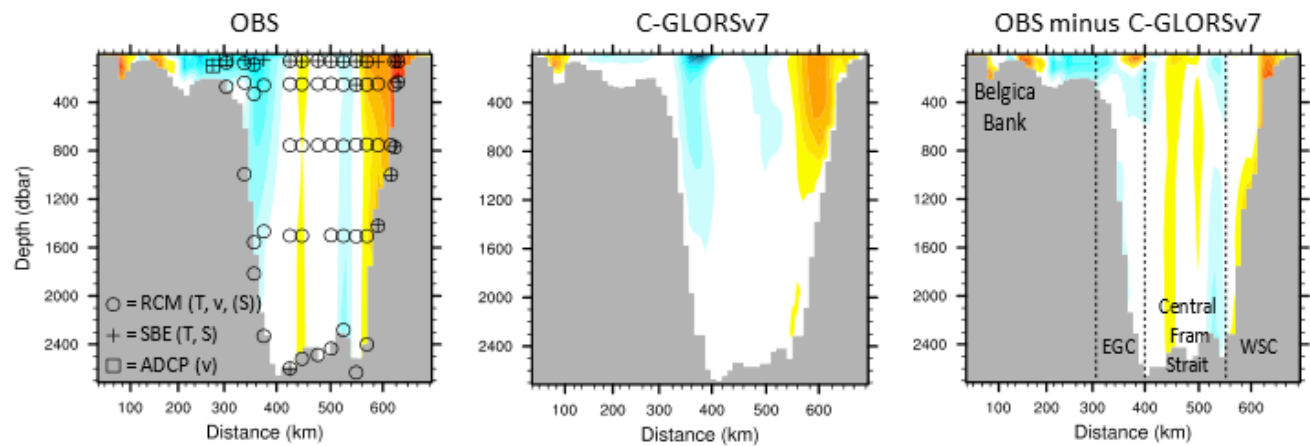

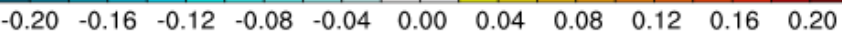

b) Potential temperature $\left({ }^{\circ} \mathrm{C}\right)$
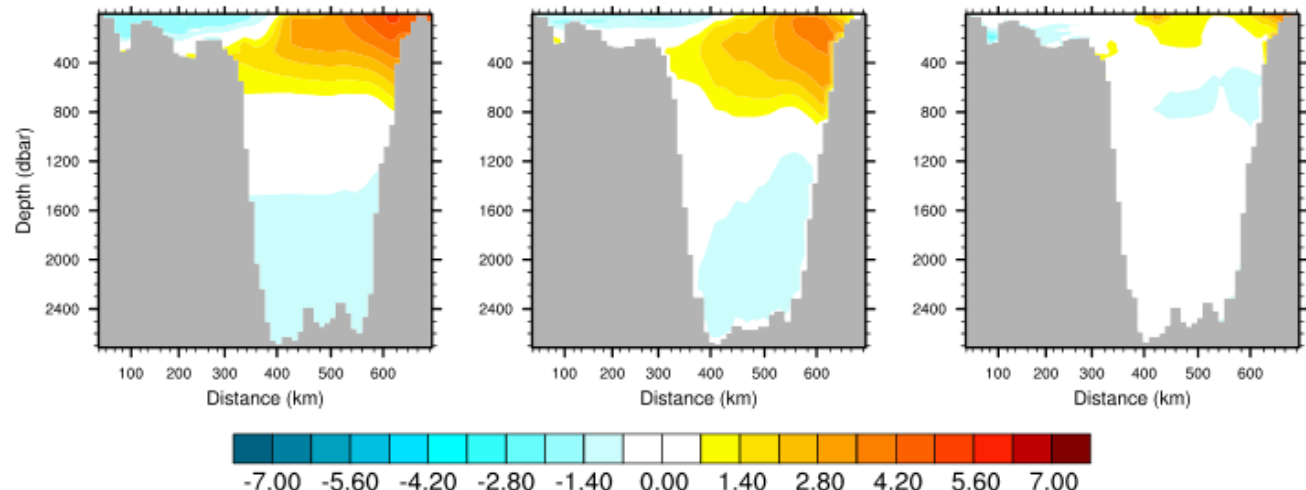

c) Temperature flux density $\left(\mathrm{W} / \mathrm{m}^{2}\right)$
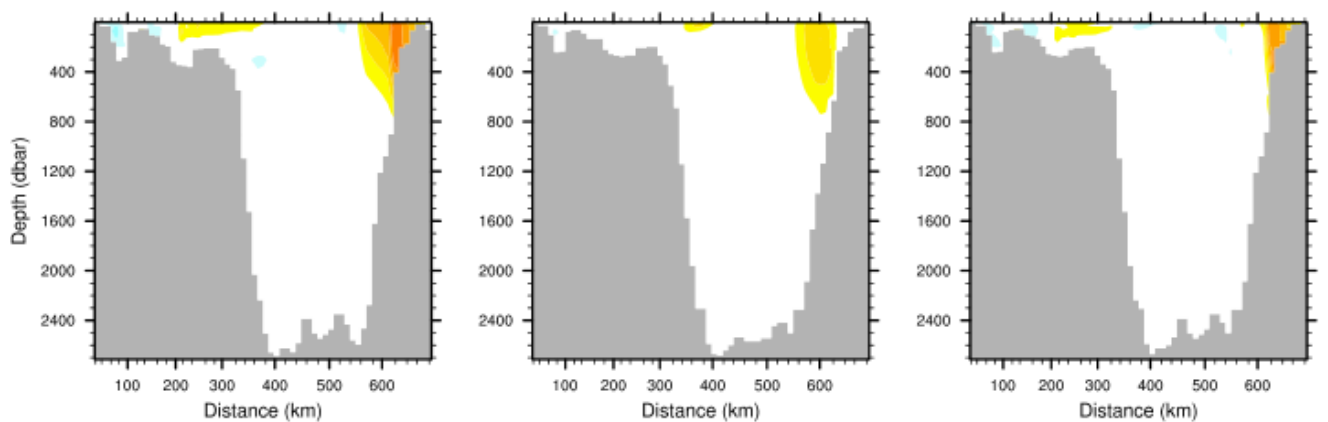

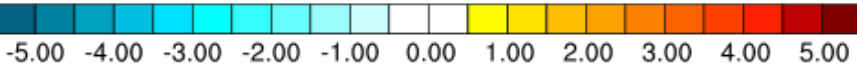

Figure 4: Fram Strait cross-sections for (a) velocity, (b) potential temperature and (c) temperature flux density averaged over the study period for the observation-based dataset (OBS), C-GLORS version 7 and the difference between the two. Distances are calculated with respect to $78.8^{\circ} \mathrm{N}$ and $20.6^{\circ} \mathrm{W}$. 
Ocean Sci. Discuss., https://doi.org/10.5194/os-2017-98

Manuscript under review for journal Ocean Sci.

Discussion started: 15 December 2017

(c) Author(s) 2017. CC BY 4.0 License.

Discussions

(c) (i)

a) Velocity $(\mathrm{m} / \mathrm{s})$
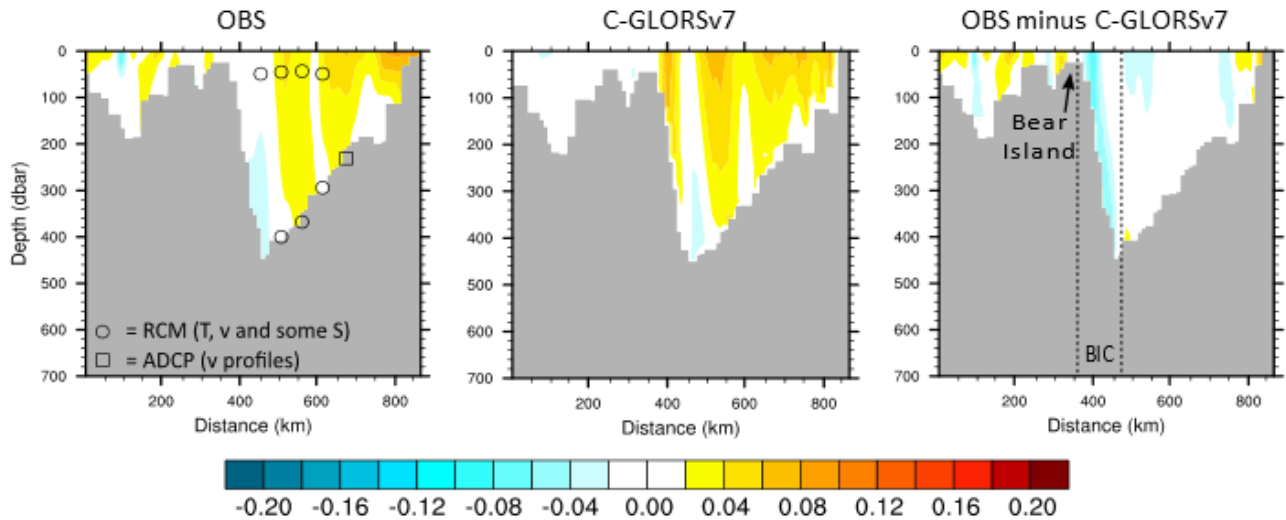

b) Potential temperature $\left({ }^{\circ} \mathrm{C}\right)$
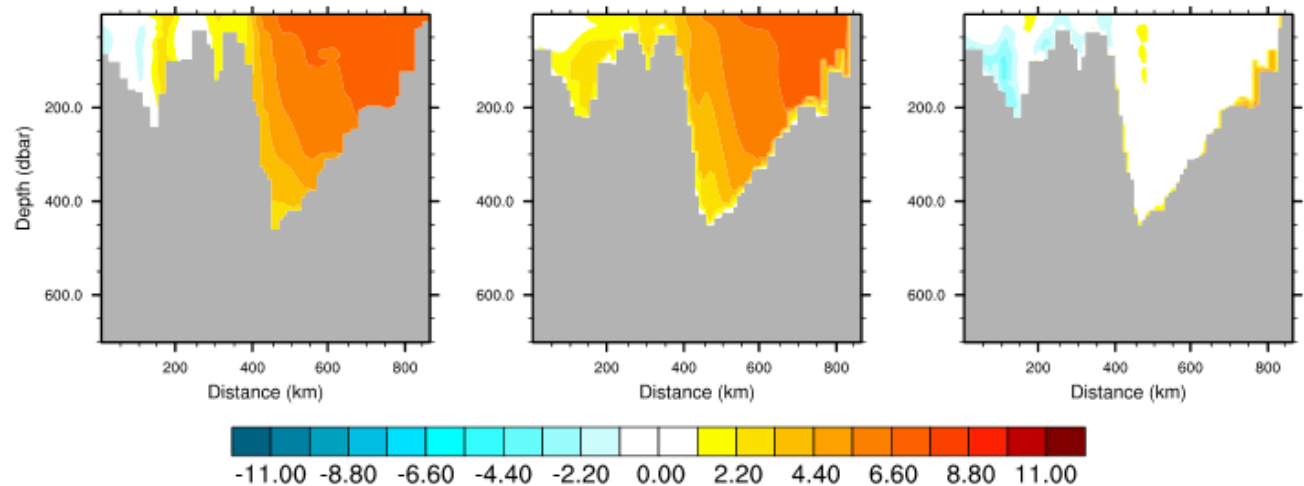

c) Temperature flux density $\left(\mathrm{W} / \mathrm{m}^{2}\right)$
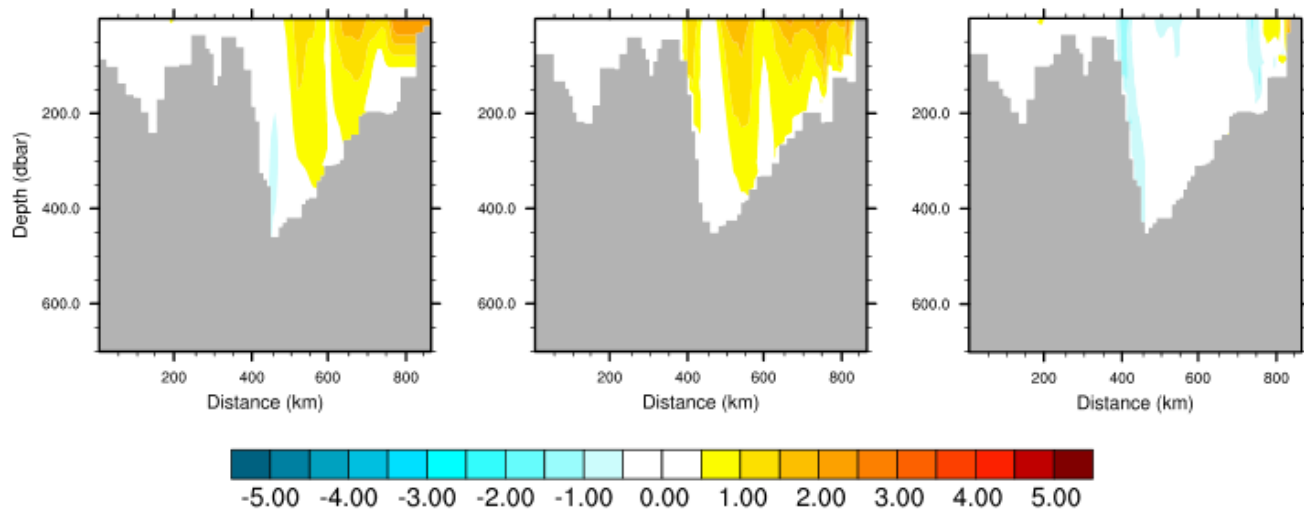

Figure 5: Barents Sea Opening cross-sections for (a) velocity, (b) potential temperature and (c) temperature flux density averaged over the study period for the observation-based dataset (OBS), C-GLORS version 7 and the difference between the two. Distances are calculated with respect to $77.5^{\circ} \mathrm{N}$ and $18.1^{\circ} \mathrm{E}$. 
Ocean Sci. Discuss., https://doi.org/10.5194/os-2017-98

Manuscript under review for journal Ocean Sci.

Discussion started: 15 December 2017
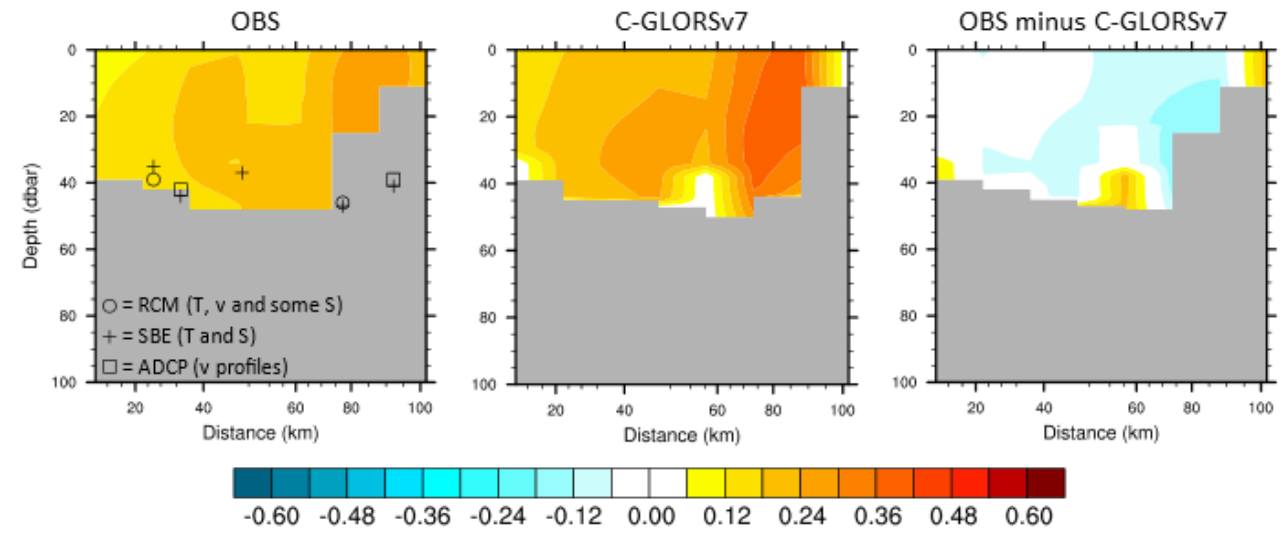

b) Potential temperature $\left({ }^{\circ} \mathrm{C}\right)$
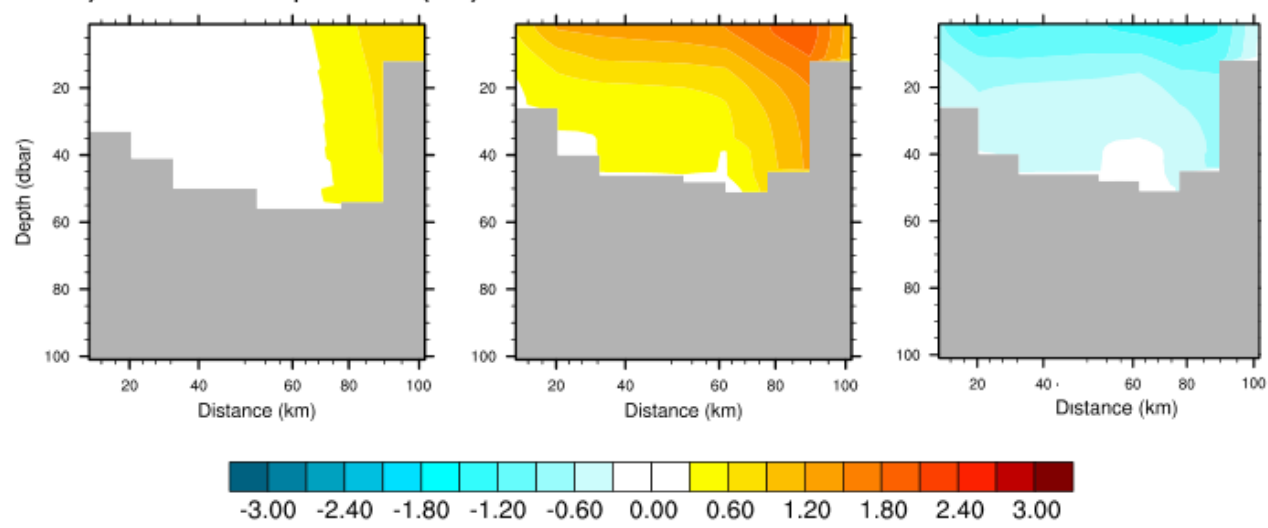

c) Temperature flux density $\left(\mathrm{W} / \mathrm{m}^{2}\right)$
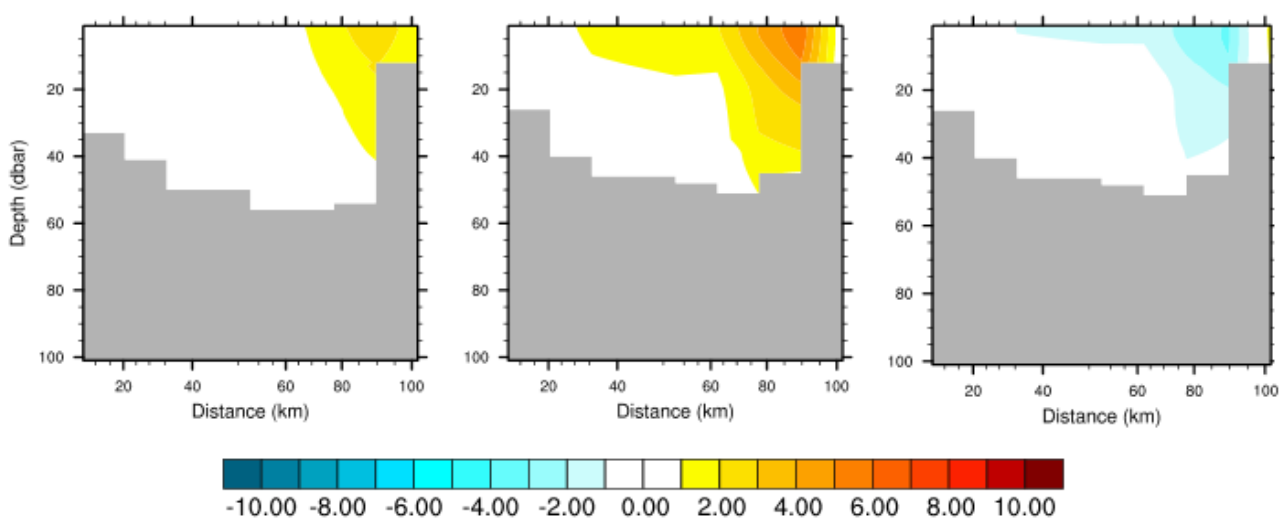

Figure 6: Bering Strait cross-sections for (a) velocity, (b) potential temperature and (c) temperature flux density averaged over the study period. Distances are calculated with respect to $66.0^{\circ} \mathrm{N}$ and $170.2^{\circ} \mathrm{W}$. The different shape of the observation-based velocity cross-sections compared to temperature and temperature flux density cross-sections is due to temperatures being given in slightly different locations and having a different spatial coverage than the velocities. Interpolation of temperatures to the velocity grid for calculating temperature transports, and horizontal averaging of the temperature, temperature flux density and velocity fields to meet the horizontal resolution of the reanalysis grid lead to different spatial coverage in the plots. The same happens in the other straits, but it is less obvious there due to the larger cross-section areas. 
Ocean Sci. Discuss., https://doi.org/10.5194/os-2017-98

Manuscript under review for journal Ocean Sci.

Discussion started: 15 December 2017

(c) Author(s) 2017. CC BY 4.0 License.

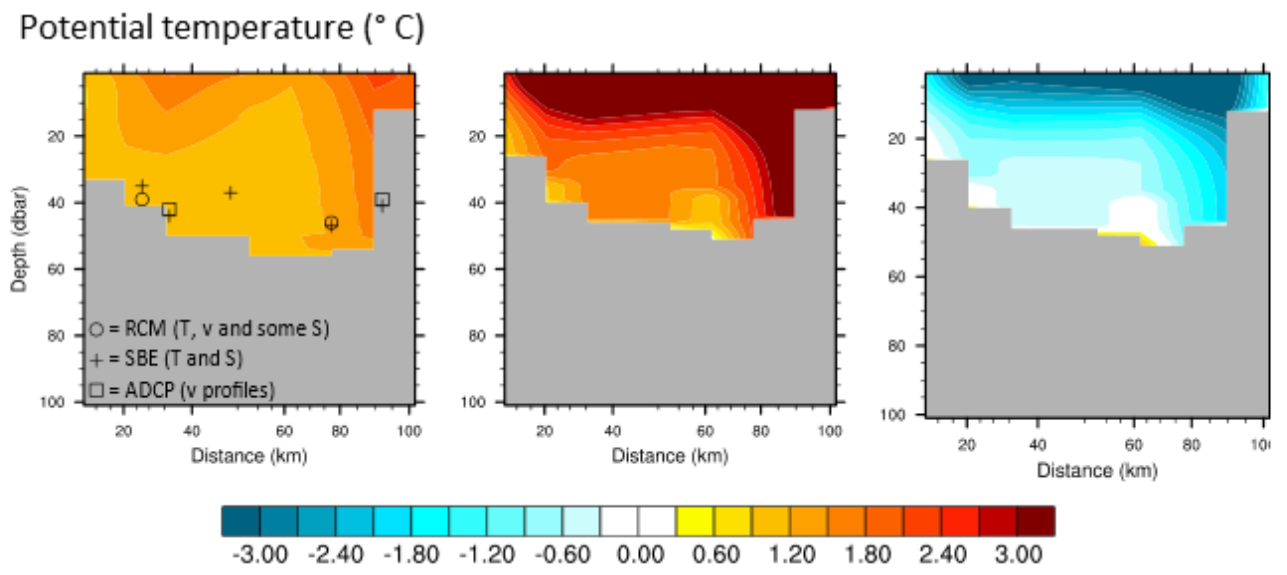

Figure 7: Bering Strait potential temperature distribution during summer 2006 (averaged over June, July and August). 
Ocean Sci. Discuss., https://doi.org/10.5194/os-2017-98

Manuscript under review for journal Ocean Sci.

Discussion started: 15 December 2017

\begin{tabular}{|c|c|c|c|c|c|c|c|c|c|c|}
\hline & \multicolumn{5}{|c|}{ Volume Transport (Sv) } & \multicolumn{5}{|c|}{ Temperature Transport (TW) } \\
\hline & OBS & C-GLORS & $r$ & RMSD & $\Delta$ & OBS & C-GLORS & $\mathbf{r}$ & RMSD & $\Delta$ \\
\hline Davis & $-2.1 \pm 0.7$ & $\begin{array}{l}-2.3 \pm 0.4 \\
-2.7 \pm 0.5\end{array}$ & $\begin{array}{l}0.56 \\
0.34\end{array}$ & $\begin{array}{l}0.57 \\
0.91\end{array}$ & $\begin{array}{l}0.2 \\
0.6\end{array}$ & $29 \pm 10$ & $\begin{array}{c}5 \pm 4 \\
23 \pm 10\end{array}$ & $\begin{array}{l}0.40 \\
0.07\end{array}$ & $\begin{array}{l}26 \\
15\end{array}$ & $\begin{array}{l}24 \\
6\end{array}$ \\
\hline Fram & $-1.1 \pm 1.2$ & $\begin{array}{l}-2.2 \pm 0.9 \\
-1.8 \pm 0.8\end{array}$ & $\begin{array}{l}0.68 \\
0.76\end{array}$ & $\begin{array}{l}1.35 \\
1.00\end{array}$ & $\begin{array}{l}1.1 \\
0.7\end{array}$ & $58 \pm 17$ & $\begin{array}{l}45 \pm 11 \\
33 \pm 9\end{array}$ & $\begin{array}{l}0.91 \\
0.74\end{array}$ & $\begin{array}{l}16 \\
28\end{array}$ & $\begin{array}{l}13 \\
25\end{array}$ \\
\hline BSO & $2.3 \pm 1.2$ & $\begin{array}{l}3.4 \pm 1.1 \\
3.3 \pm 1.0\end{array}$ & $\begin{array}{l}0.76 \\
0.69\end{array}$ & $\begin{array}{l}1.35 \\
1.32\end{array}$ & $\begin{array}{l}-1.1 \\
-1.0\end{array}$ & $63 \pm 32$ & $\begin{array}{l}89 \pm 27 \\
75 \pm 22\end{array}$ & $\begin{array}{l}0.80 \\
0.81\end{array}$ & $\begin{array}{l}32 \\
22\end{array}$ & $\begin{array}{l}-26 \\
-12\end{array}$ \\
\hline Bering & $0.7 \pm 0.7$ & $\begin{array}{l}1.0 \pm 0.6 \\
1.0 \pm 0.5\end{array}$ & $\begin{array}{l}0.97 \\
0.97\end{array}$ & $\begin{array}{l}0.36 \\
0.38\end{array}$ & $\begin{array}{l}-0.3 \\
-0.3\end{array}$ & $2 \pm 10$ & $\begin{array}{l}6 \pm 14 \\
4 \pm 14\end{array}$ & $\begin{array}{l}0.91 \\
0.95\end{array}$ & $\begin{array}{l}7 \\
5\end{array}$ & $\begin{array}{l}-4 \\
-2\end{array}$ \\
\hline Net & $-0.15 \pm 0.06$ & $\begin{array}{l}-0.03 \pm 0.23 \\
-0.16 \pm 0.22\end{array}$ & $\begin{array}{l}0.33 \\
0.12\end{array}$ & $\begin{array}{l}0.24 \\
0.21\end{array}$ & $\begin{array}{r}-0.12 \\
0.01\end{array}$ & $153 \pm 44$ & $\begin{array}{l}145 \pm 35 \\
135 \pm 37\end{array}$ & $\begin{array}{l}0.96 \\
0.91\end{array}$ & $\begin{array}{l}17 \\
25\end{array}$ & $\begin{array}{l}8 \\
18\end{array}$ \\
\hline
\end{tabular}

Table 1: This Table is a comparison of the different reanalysis experiments (C-GLORSv7 in black, the control run in blue) with the observation-based dataset (OBS). The values are the annual averages of volume and temperature transports in Sv and TW, respectively, through each strait and the net transport (sum of all straits) based on the time series (Fig. 2). Each value is given with monthly standard deviations calculated for the one-year study period. Cross correlation $r$ between C-GLORSv7 and the observation-based time series, root mean square deviation and average difference $(\Delta=$ OBS minus C-GLORSv7) are given as well. 